\title{
Preparation and Characterization of
} $\mathrm{Fe}_{3} \mathrm{O}_{4} @ M T X$ Magnetic Nanoparticles for Thermochemotherapy of Primary Central Nervous System Lymphoma in vitro and in vivo

This article was published in the following Dove Press journal:

International Journal of Nanomedicine

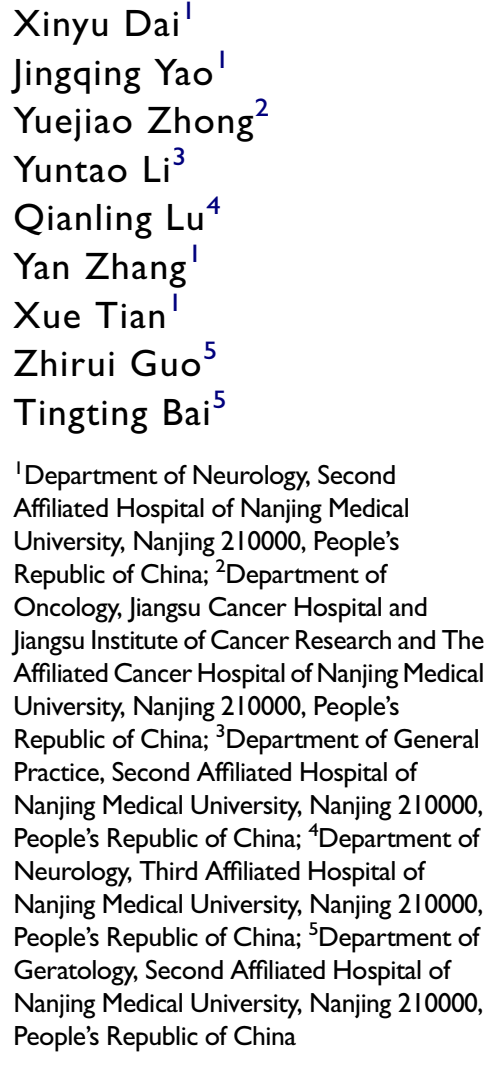

Correspondence: Yuejiao Zhong Department of Oncology, The Affiliated Cancer Hospital of Nanjing Medical University, Baiziting 42, Nanjing 210009, People's Republic of China

Email zhongyuejiao2019@163.com

Yuntao Li

Department of General Practice, Second Affiliated Hospital of Nanjing Medical University, No. 121 Jiangjiayuan Road,

Nanjing, Jiangsu, People's Republic of China Tel/Fax +8625 58509989

Email 18951762737@163.com
Background: Primary central nervous system lymphomas (PCNSL) are extranodal malignant non-Hodgkin lymphomas (NHL) that arise exclusively in central nervous system (CNS). Diffuse large B-cell lymphoma (DLBCL) is the most common histological subtype.

Purpose: To evaluate whether nano drug-loading system-mediated magnetic-targeted thermochemotherapy could produce a better therapeutic effect than single chemotherapy while reducing the use of chemotherapeutic drugs.

Methods: Six groups (control, $\mathrm{Fe}_{3} \mathrm{O}_{4}, \mathrm{MTX}, \mathrm{Fe}_{3} \mathrm{O}_{4} @ \mathrm{MTX}, \mathrm{Fe}_{3} \mathrm{O}_{4}$ with hyperthermia and $\mathrm{Fe}_{3} \mathrm{O}_{4} @$ MTX with hyperthermia) were set. Tumor cell apoptosis in each treatment group was detected by flow cytometry. Apoptosis-related gene expressions Caspase-3, Bax and Bcl-2 were detected by qPCR and Western blot; intracranial tumor model of PCNSL was established by intracranial injection of OCI-LY18 tumor cells into BALB/c-Nude mice. Magnetic resonance imaging (MRI) was used to monitor tumor progression and $\mathrm{H} \& \mathrm{E}$ staining was used to observe pathological changes of the tumor tissue.

Results: In vitro, compared with chemotherapy alone, apoptosis rate of $\mathrm{Fe}_{3} \mathrm{O}_{4} @ \mathrm{MTX}$ mediated thermochemotherapy group was significantly increased, and expression of apoptosis-inducing gene Caspase- 3 and Bax were significantly upregulated in OCI-LY18 cells, while expression of apoptosis-inhibiting Bcl-2 gene was significantly downregulated. In vivo, MRI showed successful generation of intracranial tumor, and tumor volume was significantly smaller in combined thermochemotherapy group than in single chemotherapy group. H\&E staining result of tumor tissues in each group was consistent with MRI; tumor cells were significantly reduced in thermochemotherapy group. Expression of apoptosis-related gene Caspase-3 and Bax were significantly upregulated in tumor tissues, while expression of Bcl-2 gene was significantly downregulated.

Conclusion: These results demonstrated in vivo and in vitro that the combined thermochemotherapy of $\mathrm{Fe}_{3} \mathrm{O}_{4} @$ MTX MNPs was superior to the single MTX chemotherapy with less dosage, which may promote apoptosis of DLBCL cells through the mitochondrial apoptotic pathway and provided a new way for the treatment of PCNSL.

Keywords: primary central nervous lymphoma, PCNSL, $\mathrm{Fe}_{3} \mathrm{O}_{4} @ \mathrm{MTX}$ magnetic nanoparticles, MNPs, hyperthermia, OCI-LY18 cells

\section{Key Point}

1. When drug loading efficiency was $15 \%$, the most efficient drug encapsulation was $60.9 \%$, the dose of MTX was reduced in $\mathrm{Fe}_{3} \mathrm{O}_{4} @$ MTX MNPs for thermochemotherapy compared with the single chemotherapy group. 
Therefore, we could improve the therapeutic effect while reducing the chemotherapeutic drugs.

2. In the study, we found that combined thermochemotherapy can promote apoptosis and shrink tumors. In addition, we explored the possible pathways by detecting the expression of apoptosisrelated genes Caspase-3, Bax and Bcl-2.

\section{Introduction}

Primary central nervous system lymphoma (PCNSL) is an extranodal malignant non-Hodgkin lymphomas (NHL) that arise exclusively in the CNS, including the brain, leptomeninges, spinal cord and eyes. ${ }^{1-3}$ Diffuse large B-cell lymphoma (DLBCL) is the most common histological subtype (>90\%). ${ }^{4}$ It is a rare neoplasm with a median age of 66 years at diagnosis, accounting for $2-3 \%$ of all NHL cases but in increasing incidence particularly for elderly patients. ${ }^{5,6}$ So far, the use of high-dose intravenous (IV) methotrexate (MTX) as the backbone regimens, with or without whole-brain radiotherapy and other chemotherapeutics, resulted in significantly improved efficacy, achieving response rates (RR) as high as $70-90 \%$, and median overall survival (OS) of 40-70 months., However, it is now widely recognized that the need for high doses of chemotherapy to achieve valid drug concentrations in cerebral tissues and/or radiotherapy results in a high incidence of delayed neurologic toxicity, occurring in as many as $90 \%$ of patients who are older than 60 years. ${ }^{9,10}$ Despite recent therapeutic progress and an apparent improvement in survival figures, outcomes for patients with primary CNS lymphoma remain poor with $20-30 \%$ survival at 5 years, clinical research in this field is focused predominantly on the identification of new active agents and combinations to increase efficacy and tolerability of induction chemotherapy. ${ }^{11}$

In recent times, nanotechnology is extensively offering new approaches to drug delivery, disease diagnose and therapy, especially in cancer research. Functionalization of nanoparticles with cytotoxic drugs has been proven a promising cancer therapeutic method to selectively target tumor cells and reduce systemic toxicity of drugs. ${ }^{12,13}$ One promising cancer therapeutic method is magnetic hyperthermia; tumor cells can effectively be killed by heating to hyperthermic temperatures $\left(42-45^{\circ} \mathrm{C}\right)$ during the exposure to an alternating magnetic field (AMF). ${ }^{13-18}$ It involves raising the local temperature of the local malignant tissues which results in an induced cell death without damaging the surrounding healthy tissues, therefore making the cancer cells more sensitive to the effects of certain anti-cancer drugs and minimizing the collateral damage caused by other well-established therapies. ${ }^{15,19}$ Among the nanocarriers that used for drug delivery and cancer therapy, iron oxide nanoparticles $\left(\mathrm{Fe}_{3} \mathrm{O}_{4}\right)$ are relatively easy to synthesise, biocompatible, nontoxic, chemically stable and can be superparamagnetic, which have attracted considerable attention for tumor targeting thermochemotherapy. ${ }^{19-21}$

Herein, iron oxide magnetic nanoparticles (IONPs) $\mathrm{Fe}_{3}$ $\mathrm{O}_{4}$ as a carrier can move to the tumor location with an external magnetic field after loading the drug, and produce a combined thermochemotherapy effect under magnetic resonance imaging (MRI) monitoring. ${ }^{18,22-24}$ In our study, the antitumor activity of water-dispersible Pluronic F-127/OA-coated $\mathrm{Fe}_{3} \mathrm{O}_{4} @$ MTX nanoparticle formulation was developed in order to lower the use of chemotherapy drug MTX and reduce toxic effects, at the same time achieving better inhibition of PCNSL.

\section{Materials and Methods}

\section{Materials}

The transmission electron microscope was from Hitachi (Japan). The nanoparticle tracking analysis (NTA) and Zeta potentiometer were from Malvern (United Kingdom). UV-VIS -NIR spectrophotometer UV-3600 was from Shimadzu (Japan). Vibrating sample magnetometry (VSM) PPMS-9 (Quantum Design, USA); StepOnePlus ${ }^{\mathrm{TM}}$ Real-Time PCR System (Applied Biosystems); BD FACSCantotm II Flow Cytometry (BD Biosciences, USA). A SPG-06A highfrequency induction heater was purchased from ShuangPing (Shenzhen, China). RPMI-1640 medium and DMEM medium (Gibco, Thermo Fisher Scientific), heat-inactivated fetal bovine serum (Gibco, Life Technologies), penicillinstreptomycin (Gibco, Life Technologies). Other reagents included ferric chloride $\left(\mathrm{FeCl}_{3} \cdot 6 \mathrm{H}_{2} \mathrm{O}\right)$, ferrous sulfate $\left(\mathrm{FeSO}_{4} \cdot 7 \mathrm{H}_{2} \mathrm{O}\right)$ and ammonia water $\left(\mathrm{NH}_{3} \cdot \mathrm{H}_{2} \mathrm{O}\right)$, etc. which were purchased from Shanghai First Reagent Factory (China), Methotrexate (MTX) (donated by Jiangsu Cancer Hospital and Jiangsu Institute of Cancer Research, Nanjing, Jiangsu, China). Cell Counting Kit-8, CCK-8 (KeyGEN BioTECH, China), RNA pure Tissue \& Cell Kit (DNase I) (Cwbiotech, China). Quantitative Real-time-PCR related reagents were purchased from Vazyme (Vazyme Biotech Co., Ltd, China), Caspase-3 primer, Bax primer, Bcl-2 primer and GAPDH primer were purchased from Invitrogen. Goat antiRabbit IgG (KeyGEN BioTECH, China), GAPDH (KeyGEN 
BioTECH, China), Caspase-3 antibody, Bax antibody and Bcl2 antibody were purchased from Cell Signaling Technology (USA). All reagents were analytical grade.

\section{Cells and Animals}

3T3 cells were purchased from Shanghai Institute of Cell Biology (Shanghai, China). DLBCL cell line (OCI-LY18 cells) were from DSMZ (Biomart, China). KM mice (male and female, SPF grade), age-matched (4-6 weeks of age) and weight-matched (20-25 g) were purchased from Cavens Lab Animal Company (Changzhou, China, License number: SCXK (Jiangsu) 2016-0010); BALB/c-Nude mice (male and female, SPF grade), age-matched (4-6 weeks of age) and weight-matched (18-22 g) were purchased from Animal Core Facility of Nanjing Medical University. The ethical review has passed by Nanjing Medical University (Approval No. IACUC-1810012), and the relevant experimental personnel are certified. All animals received humane care in compliance with the "Principles of Laboratory Animal Care" formulated by the National Society for Medical Research and the "Guide for the Care and Use of Laboratory Animals" prepared by the Institute of Laboratory Animal Resources and published by the National Institutes of Health (NIH Publication No 86-23, revised 1996). Animal modeling was assessed by MRI, tumor volume was calculated and compared among each group of treatment.

\section{Preparation of $\mathrm{Fe}_{3} \mathrm{O}_{4}$ MNPS}

Based on previous research ${ }^{25}, 28 \mathrm{~g}$ of $\mathrm{FeCl}_{3} \cdot 6 \mathrm{H}_{2} \mathrm{O}, 20 \mathrm{~g}$ of $\mathrm{FeSO}_{4} \cdot 7 \mathrm{H}_{2} \mathrm{O}$ were dissolved in deoxygenated $\mathrm{ddH}_{2} \mathrm{O}$, kept stirring with nitrogen until the temperature of the system exceeded $70^{\circ} \mathrm{C}$. $40 \mathrm{ml} \mathrm{NH}_{3} \cdot \mathrm{H}_{2} \mathrm{O}$ and $5 \mathrm{ml} \mathrm{OA}$ were added in sequence. After washing the OA-coated MNPS, Pluronic F-127 was added, followed by magnetic stirring overnight. The larger particles were removed by centrifugation at low speed, and then centrifuged at high speed to discard the excess Pluronic F-127. Finally, stable Pluronic F-127/OA-coated MNPs were obtained and stored at $4^{\circ} \mathrm{C}$ for further use.

\section{Encapsulation and Cumulative Release of MTX}

We set series of concentrations of MTX and Pluronic F-127/ OA-coated MNPs (MTX:Fe = 5, 10, 15, 20, 25, 30, 35, 40; \% $\mathrm{W} / \mathrm{W}$ ) disperse in phosphate-buffered solution (PBS). The mixture was shaken and incubated at $25^{\circ} \mathrm{C}$ for $72 \mathrm{hrs}$ to allow MTX to be entrapped into OA layer. Free MTX was removed by magnetic separation. The supernatant was discarded and the complexes were resuspended and sonicated in PBS buffer to form a homogeneous solution and stored at $4^{\circ} \mathrm{C}$. The amount of non-entrapped MTX in aqueous phase was determined using UV-VIS-NIR spectrophotometer (370nm; Shimadzu, Japan). The amount of MTX entrapped within the nanoparticles was calculated by the difference between the total amount used to prepare the nanoparticles and drug encapsulation efficiency was calculated as follows: (amount of loaded drug in $\mathrm{mg}) /($ amount of added drug in $\mathrm{mg}) \times 100 \%$; Drug loading was calculated as follows: (amount of loaded drug in $\mathrm{mg}) /($ amount of MNPs in $\mathrm{mg}) \times 100 \%$.

Furthermore, the drug release study of $\mathrm{Fe}_{3} \mathrm{O}_{4} @ \mathrm{MTX}$ MNPs was carried out in pH 7.4 PBS. The released MTX concentrations from the nano-carriers were determined by UV-VIS-NIR spectrophotometer; supernatants from $\mathrm{Fe}_{3} \mathrm{O}_{4}$ @MTX complexes were collected after magnetic separation within three days (after 2 hrs, 4 hrs, 6 hrs, 12 hrs, 24 hrs, $48 \mathrm{hrs}, 72 \mathrm{hrs}$ ) at $25^{\circ} \mathrm{C}$ and $42^{\circ} \mathrm{C}$, respectively.

\section{Characterization of $\mathrm{Fe}_{3} \mathrm{O}_{4} \mathrm{MNPs}$ and $\mathrm{Fe}_{3}$ $\mathrm{O}_{4} @ M T X$ MNPs}

The $\mathrm{Fe}_{3} \mathrm{O}_{4}$ MNPs and $\mathrm{Fe}_{3} \mathrm{O}_{4} @$ MTX MNPs samples were spread onto 400 mesh copper grids. The size and shape of the $\mathrm{Fe}_{3} \mathrm{O}_{4}$ nanoparticles were determined by TEM (Hitachi, Japan). The NTA (Malvern, UK) was used to detect size distribution, and the magnetic properties of the nanoparticles were analyzed by vibrating sample magnetometry (Quantum Design, USA) at room temperature. Zeta potential was measured using Malvern Instruments (Malvern, UK).

\section{Increasing Temperature Tests}

Magnetothermal effects of MNPs were tested in aqueous suspensions $(0.5,1.0,1.5 \mathrm{mg} \mathrm{Fe} / \mathrm{mL})$. The solution was placed in a flat-bottomed test tube on an SPG-06A highfrequency induction heater $(\mathrm{f}=230 \mathrm{kHz}$; I $=30 \mathrm{~A}$; Shenzhen, China) for 60 mins. The temperature was recorded at 5-mins intervals.

\section{Biocompatibility \\ Cell Culture}

$3 \mathrm{~T} 3$ cells were maintained in DMEM medium (Gibco, Thermo Fisher Scientific), mixed with 10\% fetal bovine serum (Gibco, Life Technologies) and 1\% penicillin-streptomycin (Gibco, Life Technologies) in a standard $5 \% \mathrm{CO}_{2}$ and $37^{\circ} \mathrm{C}$ incubator. 
The cells were passaged every 2-3 days and harvested on exponential growth stage.

\section{CCK-8 Cytotoxicity Test}

CCK-8 assay was used to evaluate cell toxicity. 3T3 cells were seeded in 96-well plates (8000 cells per well) for 24 hrs in DMEM medium. Then they were divided into eleven groups (four wells per group) and incubated with various concentrations of $\mathrm{Fe}_{3} \mathrm{O}_{4} \mathrm{MNPs}$ solution and $\mathrm{Fe}_{3} \mathrm{O}_{4}$ (a)MTX MNPs solution (Fe concentration: 20, 40, 60, 80, 100, 200, 300, 400, $500 \mu \mathrm{g} / \mathrm{mL}$ ), control group (DMEM medium containing $10 \%$ fetal bovine serum) and blank group (DMEM medium containing 10\% fetal bovine serum without cells) for $24 \mathrm{hrs}$. Inverted microscopy (Olympus, Japan) was used to observe general morphological changes of the $3 \mathrm{~T} 3$ cells, and then the CCK-8 assay was performed and the optical density (OD) values were measured at $450 \mathrm{~nm}$. The cell viability was calculated as follows: (OD of experimental group-OD of blank group)/ (OD of negative control group-OD of blank group)

\section{Micronucleus Assay of $\mathrm{Fe}_{3} \mathrm{O}_{4}$ MNPs}

The KM mice were randomly divided into six groups, with five females and five males in each group. The animals were then treated with four concentrations of $\mathrm{Fe}_{3} \mathrm{O}_{4} \mathrm{MNPs}$ $(5.00,3.75,2.50$ and $1.25 \mathrm{~g} / \mathrm{kg}), 0.9 \%$ saline (as negative group) and Cyclophosphamide (CTX) $40 \mathrm{mg} / \mathrm{kg}$ (as positive group), respectively. All experimental mice were injected intraperitoneally twice, with a 24-hrs interval, and then sacrificed $6 \mathrm{hrs}$ after the second administration. The thighbone marrows were extracted for smears, fixed 15 mins with methanol, and then washed slides after stained with Giemsa for 15 mins. At least 1000 polychromatic erythrocytes (PEC) were counted for each mouse, and the rate of formation of PEC containing micronucleus (MN) was calculated. SPSS was used to analyze statistic difference between each group.

\section{Acute Toxicity Testing of $\mathrm{Fe}_{3} \mathrm{O}_{4} @ M T X$ MNPs}

The KM mice were randomly assigned into eight groups, with five females and five males in each group. After dissolved in $0.9 \%$ saline, $\mathrm{Fe}_{3} \mathrm{O}_{4} @ \mathrm{MTX}$ MNPs were injected intraperitoneally into the mice at dosages of $1.77,2.51,3.54,5.00,7.06,9.98,14.09$, and $19.89 \mathrm{~g} / \mathrm{kg}$. The general behavior of the mice was observed continuously for 2 hrs immediately after injection and then intermittently observed for a period of 24 hrs. All mice were further observed for up to 14 days after injection, and general physical states, including eating, rest and movement were monitored. Any toxic reaction and death were recorded. Median lethal dose $\left(\mathrm{LD}_{50}\right)$ was evaluated by SPSS. The animals were euthanized after all of the experiment.

\section{In vitro Evaluation of the Efficacy of $\mathrm{Fe}_{3}$ $\mathrm{O}_{4} @ M T X$ MNPs on OCl-LY8 PCNSL Cells}

\section{Cell Culture and Perls Stain}

An OCI-LY8 DLBCL cell line was cultured in RPMI1640 medium (Gibco, Thermo Fisher Scientific) supplemented with 10\% heat-inactivated fetal bovine serum (Gibco, Life Technologies), 1\% penicillin-streptomycin (Gibco, Life Technologies) and incubated at $37^{\circ} \mathrm{C}$ with humidified air containing $5 \% \mathrm{CO}_{2}$.

OCI-LY 8 cells were seeded into a culture dish $\left(1 \times 10^{6}\right.$ cells) with fresh medium and incubated $\left(37^{\circ} \mathrm{C}, 5 \% \mathrm{CO}_{2}\right)$ overnight. The growth medium was then discarded and replaced with fresh medium containing $\mathrm{Fe}_{3} \mathrm{O}_{4} @ \mathrm{MTX}$ MNPs (Fe concentration: $1.0 \mathrm{mg} / \mathrm{mL}$ ). The cells were incubated $\left(37^{\circ} \mathrm{C}, 5 \% \mathrm{CO}_{2}\right)$ for an additional $1 \mathrm{hr}$; after that, the medium was discarded and cells washed. After fixation by methanol, cells were stained by Perls and observed with an inverted microscope.

\section{Flow Cytometry}

OCI-LY8 cells were seeded in culture flasks $\left(5 \times 10^{5}\right.$ cells per flask) and divided into six groups as follows: 1) control group (2 mL RPMI1640 medium); 2) $\mathrm{Fe}_{3} \mathrm{O}_{4}$ MNPs group ( $1 \mathrm{mg} \mathrm{Fe} / \mathrm{mL}$ in $2 \mathrm{~mL}$ RPMI1640 medium); 3) MTX group (1mg/mL MTX in $2 \mathrm{~mL}$ RPMI1640 medium); 4) $\mathrm{Fe}_{3} \mathrm{O}_{4}$ @MTX MNPs group (1 mg Fe/mL in $2 \mathrm{~mL}$ RPMI1640 medium); 5) $\mathrm{Fe}_{3} \mathrm{O}_{4} \mathrm{MNPs}+$ hyperthermia group (1 mg Fe/ $\mathrm{mL}$ in $2 \mathrm{~mL}$ RPMI1640 medium) and 6) $\mathrm{Fe}_{3} \mathrm{O}_{4} @$ MTX MNPs + hyperthermia group (1 $\mathrm{mg} \mathrm{Fe} / \mathrm{mL}$ in $2 \mathrm{~mL}$ RPMI1640 medium). Cells were incubated in a humidified incubator $\left(37^{\circ} \mathrm{C}, 5 \% \mathrm{CO}_{2}\right)$ for $48 \mathrm{hrs}$. For combined hyperthermia groups, cells were placed at AMF ( $\mathrm{f}=230$ $\mathrm{kHz}, \mathrm{I}=30 \mathrm{~A}$ ) for $1 \mathrm{hr}$ after $24 \mathrm{hrs}$. After that, cells were collected and cell apoptosis analysis was performed with FCM (BD Biosciences, USA).

\section{Quantitative Real-Time Polymerase Chain Reaction (qPCR)}

Total RNA was extracted from six groups of cells (control group, $\mathrm{Fe}_{3} \mathrm{O}_{4}$ MNPs group, MTX group, $\mathrm{Fe}_{3} \mathrm{O}_{4} @ \mathrm{MTX}$ MNPs group, $\mathrm{Fe}_{3} \mathrm{O}_{4} \mathrm{MNPs}+$ hyperthermia group, $\mathrm{Fe}_{3} \mathrm{O}_{4}$ @MTX MNPs + hyperthermia group, each group was 
treated as above) using RNApure Tissue\&Cell Kit (Cwbiotech, China) and dissolved in DEPC-treated water. After reverse transcription, the qPCR was performed in a $10 \mu \mathrm{L}$ total volume (Vazyme Biotech Co., Ltd, China) comprising $5 \mu \mathrm{L}$ of $2 \times$ ChamQ SYBR qPCR Master Mix, $0.2 \mu \mathrm{L}$ of $50 \times$ ROX Reference Dye $1,0.2 \mu \mathrm{L}$ of 5 'primer $(10 \mu \mathrm{M}), 0.2 \mu \mathrm{L}$ of 3 'primer $(10 \mu \mathrm{M}), 2.4 \mu \mathrm{L}$ of ddH2O and $2 \mu \mathrm{L}$ of cDNA on the StepOnePlus ${ }^{\mathrm{TM}}$ Real-Time PCR System (Applied Biosystems). The melting curve and threshold cycle data for each PCR product were determined and analyzed. The sequences of the specific primers used in the research were as follows $\left(5^{\prime}-3^{\prime}\right)$ : Caspase3-forward: TGGAATGACATCTCGGTC

TG and reverse: GGCTCAGAAGCACACAAACA; Bax-forward: TTTGCTTCAGGGTTTCATCC and reverse: CAGTTGAAGTTGCCGTCAGA; Bcl-2-forward: GCACA AATACTCCGCAAGAGA and reverse: GAGAGAATGT TGGCGTCTTG; GAPDH-forward: GAAGGTGAAGGTC GGAGTC and reverse: GAAGATGGTGATGGGATTTC.

\section{Western Blot}

OCI-LY8 cells under different treatments (control group, $\mathrm{Fe}_{3}$ $\mathrm{O}_{4}$ MNPs group, MTX group, $\mathrm{Fe}_{3} \mathrm{O}_{4} @$ MTX MNPs group, $\mathrm{Fe}_{3} \mathrm{O}_{4} \mathrm{MNPs}+$ hyperthermia group, $\mathrm{Fe}_{3} \mathrm{O}_{4} @ \mathrm{MTX}$ MNPs + hyperthermia group as above) were lysed, and the protein concentrations were assessed using BCA assay. Proteins were separated using sodium dodecyl sulfate-polyacrylamide gel electrophoresis and transferred from gel to polyvinylidene difluoride membranes. The membranes were blocked with nonfat milk and after the overnight incubation at $4^{\circ} \mathrm{C}$ with primary antibodies goat anti-Rabbit IgG (KeyGEN BioTECH, diluted 1:5000), membranes were washed and incubated with secondary antibodies for $2 \mathrm{hrs}$ in dark (Caspase-3 antibody,
1:1000; Bax antibody, 1:1000; Bcl-2 antibody, 1:1000; GAPDH, 1:1000); then, the bands were set into molecular imager and signals were detected.

\section{In vivo Evaluation of the Efficacy of $\mathrm{Fe}_{3} \mathrm{O}_{4}$ @MTX MNPs on Intracranial Tumor BALB/c-Nude Mice Model \\ Establishment of Intracranial Tumor Models}

Cultured OCI-LY8 cells were washed three times with PBS, counted and kept on ice in DMEM until injection. After anesthetized with $1 \%$ pentobarbital, mice were placed in a stereotactic frame. All BALB/c-Nude mice were injected in the right cerebral hemisphere with $5 \times 10^{5}$ OCI-LY8 cells (5 $\mu \mathrm{L}, 1 \mu \mathrm{L} / \mathrm{min}$ ) at $2.0 \mathrm{~mm}$ lateral and coordinates $0.5 \mathrm{~mm}$ anterior from the bregma and at an intraparenchymal depth of $3 \mathrm{~mm}$. After injection, the needle was left in place for 5 mins after injection. All animal experiments were done following institutional ethics guidelines.

\section{MRI}

The life state of the mice was observed daily after the operation, and tumor growth was monitored continuously by MRI after one week. After 12 days, tumor-bearing mice with tumor diameter of $0.5 \mathrm{~cm}$ were selected for followed experiments. Successfully modeled BALB/c-Nude mice were divided into six groups (4 mice in each group, half male and half female) as follows: 1) $\mathrm{NaCl}$ group (0.02 mL); 2) $\mathrm{Fe}_{3}$ $\mathrm{O}_{4}$ MNPs group (1 mg Fe/mL in $0.02 \mathrm{~mL} \mathrm{NaCl}$ ); 3) MTX group (1mg/mL MTX in $0.02 \mathrm{~mL} \mathrm{NaCl}$ ); 4) $\mathrm{Fe}_{3} \mathrm{O}_{4} @ \mathrm{MTX}$ MNPs group (1 mg Fe/mL in $0.02 \mathrm{~mL} \mathrm{NaCl}$ ); 5) $\mathrm{Fe}_{3} \mathrm{O}_{4}$ MNPs + hyperthermia group $(1 \mathrm{mg} \mathrm{Fe} / \mathrm{mL}$ in $0.02 \mathrm{~mL}$ $\mathrm{NaCl}$ ) and 6) $\mathrm{Fe}_{3} \mathrm{O}_{4} @$ MTX MNPs + hyperthermia group ( $1 \mathrm{mg} \mathrm{Fe} / \mathrm{mL}$ in $0.02 \mathrm{~mL} \mathrm{NaCl}$ ). The configured solution was
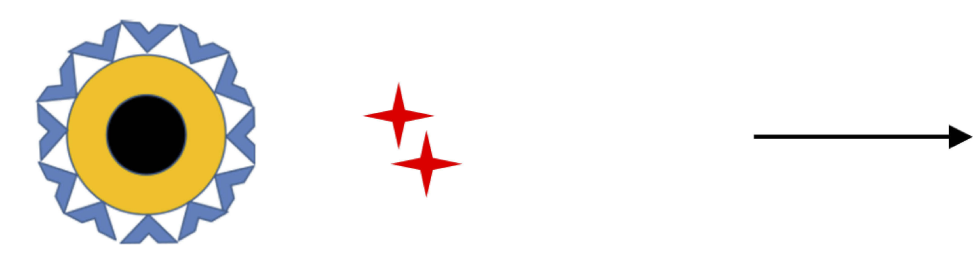

OA
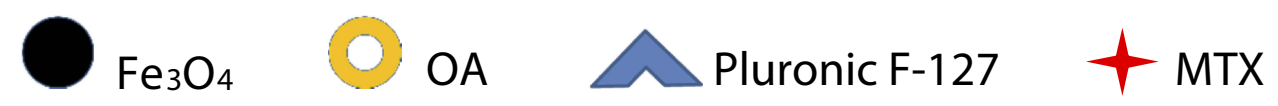

Figure I Pattern diagram of $\mathrm{Fe}_{3} \mathrm{O}_{4} @ M T X$ MNPs synthesis process.

Notes: OA was chemisorbed on the surface of the $\mathrm{Fe}_{3} \mathrm{O}_{4}$ MNPs, MTX dispersed into the OA shell surrounding $\mathrm{Fe}_{3} \mathrm{O}_{4} \mathrm{MNPs}$, and the Pluronic $\mathrm{F}-\mathrm{I} 27$ that anchored at the OA-water interface conferred aqueous dispersity to the system.

Abbreviations: MNPs, magnetic nanoparticles; OA, oleic acid. 
injected through the tail vein, and then, a strong magnet was placed above the head of the mice in combined hyperthermia groups. For heating, the tumors were exposed to AMF ( $\mathrm{f}=$ $230 \mathrm{kHz}, \mathrm{I}=30 \mathrm{~A}$ ) three times for $1 \mathrm{hr}$ each and a time interval of $24 \mathrm{hrs}$.

After six weeks of treatment, tumor size and targeted aggregation of MNPs were detected by MRI. Tumor size was calculated by the formula: $V=1 / 2 \times a \times b^{2}$ (V: tumor volume; a: the longest diameter; $b$ : the shortest diameter).

\section{H\&E Stain}

Brains were removed after perfusion, part of the tumor tissues in each group were fixed, embedded, sectioned and stained with hematoxylin \& eosin (H\&E) for histopathologic analysis.

\section{qPCR and Western Blot of Tumor Tissues}

Part of tumor was then harvested and processed for determination of qPCR and Western blot. The tissues were fully ground in liquid nitrogen, and then the corresponding RNA and protein were extracted after adding the lysate separately. The following processes of quantifying and displaying the strips are as described above.

\section{Statistical Analysis}

All statistical analyses were analyzed with SPSS version 19.0 software (SPSS Inc., Chicago, IL, USA); PS, Image $\mathrm{J}$ and Origin were commonly used mapping software. Values are shown as mean \pm standard deviation (SD). A P-value of 0.05 was considered to be statistically significant.
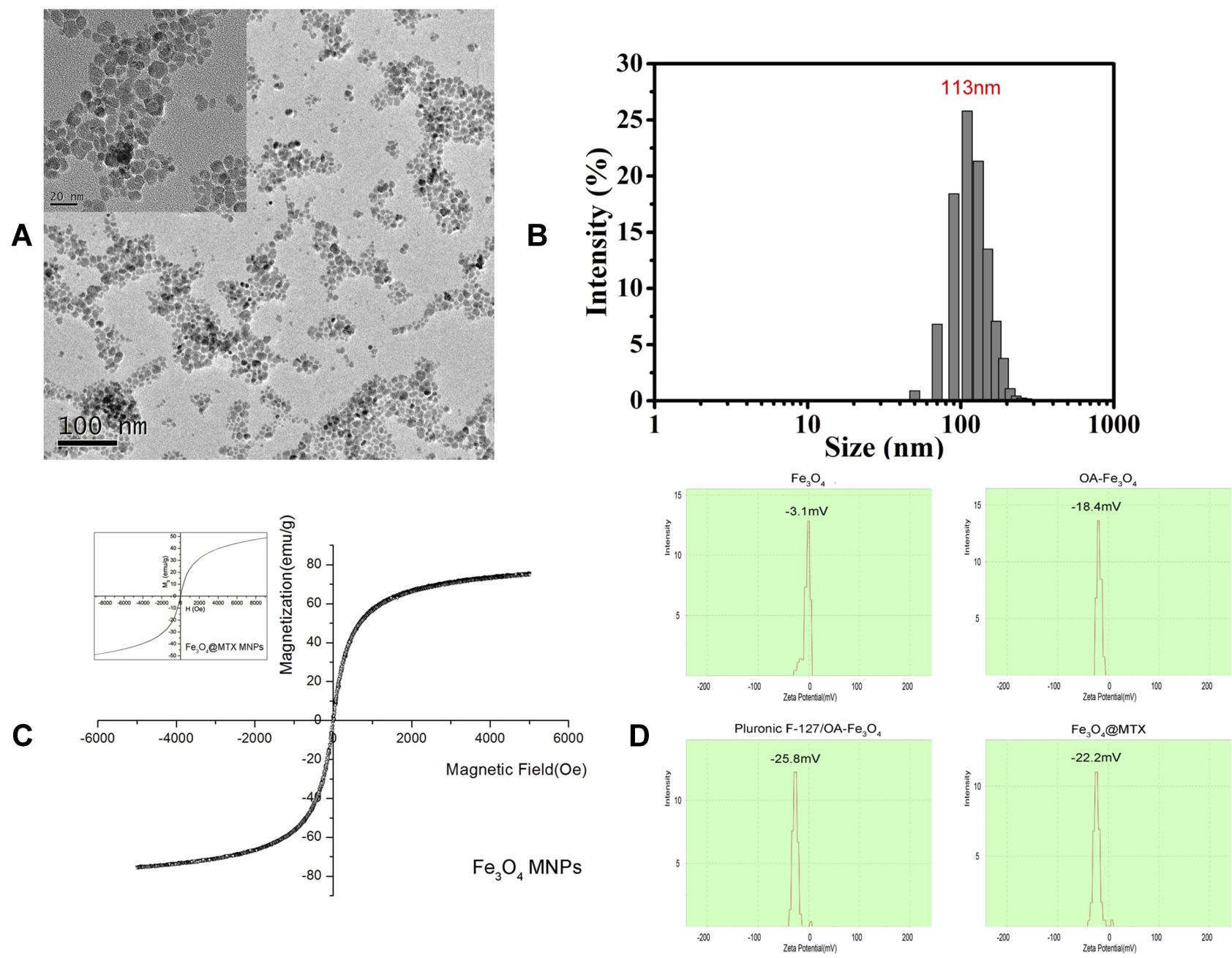

Figure 2 Characterization of $\mathrm{Fe}_{3} \mathrm{O}_{4} @ M T X$ composite magnetic nano drug-loading system. (A) Transmission electron microscopy image of Fe $\mathrm{O}_{4}$ MNPs carrier; (B) Hydrodynamic diameter and particle size distribution of $\mathrm{Fe}_{3} \mathrm{O}_{4} @ M T X$ MNPs obtained by nanoparticle tracking analysis; (C) The hysteresis loops of Fe $\mathrm{O}_{4} \mathrm{MNPs}$ and Fe $\mathrm{O}_{4}$ @MTX MNPs (insert); (D) Zeta potential of $\mathrm{Fe}_{3} \mathrm{O}_{4}$ MNPs, OA- $\mathrm{Fe}_{3} \mathrm{O}_{4}$ MNPs, Pluronic-FI27/OA $\mathrm{Fe}_{3} \mathrm{O}_{4} \mathrm{MNPs}$ and Fe $3 \mathrm{O}_{4} @ M T X M N P s$.

Abbreviations: MNPs, magnetic nanoparticles; OA, oleic acid. 


\section{Results}

Preparation and Characterization of $\mathrm{Fe}_{3}$ $\mathrm{O}_{4}$ MNPs and $\mathrm{Fe}_{3} \mathrm{O}_{4} @$ MTX MNPs

We have developed a water-dispersible Pluronic F-127/OAcoated iron oxide magnetic nanoparticle formulation $\mathrm{Fe}_{3} \mathrm{O}_{4}$ @MTX MNPs. OA was chemisorbed on the surface of the $\mathrm{Fe}_{3} \mathrm{O}_{4}$ MNPs, MTX dispersed into the OA shell surrounding $\mathrm{Fe}_{3} \mathrm{O}_{4} \mathrm{MNPs}$, and the Pluronic F-127 that anchored at the OAwater interface conferred aqueous dispersity to the system (Figure 1). TEM showed $\mathrm{Fe}_{3} \mathrm{O}_{4}$ MNPs' core to be approximately spherical in shape and the particles were uniform in size relatively, $16 \mathrm{~nm}$ in diameter (Figure 2A). Whole composite $\mathrm{Fe}_{3} \mathrm{O}_{4} @ M T X$ MNPs size and size distribution were measured by NTA (Figure 2B). It showed that the formulation had an average hydrated diameter of $113 \mathrm{~nm}$ with a single peak and a narrow particle size distribution. Moreover, the magnetic properties of $\mathrm{Fe}_{3} \mathrm{O}_{4}$ MNPs and $\mathrm{Fe}_{3} \mathrm{O}_{4} @$ MTX MNPs were analyzed by VSM at room temperature. Figure $2 \mathrm{C}$ shows the hysteresis loops of the samples; there was no hysteresis in the magnetization, with both remanence and coercivity being zero, providing a good demonstration of the superparamagnetic properties. Zeta potential of $\mathrm{Fe}_{3} \mathrm{O}_{4} \mathrm{MNPs}$, OA-coated $\mathrm{Fe}_{3} \mathrm{O}_{4}$ MNPs and Pluronic F-127/OA-coated $\mathrm{Fe}_{3} \mathrm{O}_{4}$ MNPs were detected, respectively (Figure 2D). And, results show that modified MNPs are more stable than unmodified particles, especially Pluronic F-127/OA-coated $\mathrm{Fe}_{3} \mathrm{O}_{4}$ MNPs.

\section{Encapsulation and Cumulative Release of MTX}

Drug encapsulation efficiency and drug loading efficiency of nanoparticles are crucial properties for their clinical application. The amount of drug loaded was calculated by measuring the amount of MTX remaining in supernatants. Figure 3 and Table 1 reveal the optimal drug encapsulation efficiency and drug loading efficiency. When drug loading efficiency was $15 \%$, drug encapsulation efficiency reached the maximum value of $60.9 \%$, which was selected for the next study.

Release of MTX from the complex was also determined by UV-VIS-NIR spectrophotometer, and the cumulative release at various time points was summed (Figure 4). The drug release occurred in two phases: an initial burst release, with a significant amount of drug released within $12 \mathrm{hrs}$; after $12 \mathrm{hrs}$, the MTX release profiles showed a sustained release pattern and cumulative amount reached $26.3 \%$ at $25^{\circ} \mathrm{C}$, up to $33.3 \%$ at $42^{\circ} \mathrm{C}$ within $72 \mathrm{hrs}$.

\section{Increasing Temperature Tests}

The iron concentrations of the $\mathrm{Fe}_{3} \mathrm{O}_{4}$ MNPs were set 0.5, 1.0 and $1.5 \mathrm{mg} \mathrm{Fe} / \mathrm{mL}$, respectively. It demonstrated that the temperature of $\mathrm{Fe}_{3} \mathrm{O}_{4} \mathrm{MNPs}$ in $\mathrm{AMF}$ could quickly rise to $35.5^{\circ} \mathrm{C}, 37.2^{\circ} \mathrm{C}$ and $39.9^{\circ} \mathrm{C}$ within 25 mins. After 30 mins, the temperature rose gently and almost remained at $38.5^{\circ} \mathrm{C}-44.1^{\circ} \mathrm{C}$ which was sufficient for heating efficacy (Figure 5A). Here, we chose $1.0 \mathrm{mg} \mathrm{Fe} / \mathrm{mL}$ as the subsequent therapeutic concentration and compared the heating capacity of $\mathrm{Fe}_{3} \mathrm{O}_{4} @ \mathrm{MTX}$ MNPs of the same iron concentration with $\mathrm{ddH}_{2} \mathrm{O}$, as shown in Figure $5 \mathrm{~B}$.

\section{Biocompatibility Cell Cytotoxicity}

The morphological changes of $3 \mathrm{~T} 3$ cells after treatment with different concentrations of $\mathrm{Fe}_{3} \mathrm{O}_{4} \mathrm{MNPs}$ and $\mathrm{Fe}_{3} \mathrm{O}_{4}$ (MTX MNPs were observed by inverted microscopy. With the same Fe concentration, shapes and growth of the $\mathrm{Fe}_{3} \mathrm{O}_{4} \mathrm{MNPs}$-treated cells were basically similar to normal cells; they exhibited clear edges, and no cell fragments, while most of the $\mathrm{Fe}_{3} \mathrm{O}_{4} @$ MTX MNPs-treated cell became round and fell off (Figure 6A). The results of the CCK-8 assay were shown in Figure 6B. When at $500 \mu \mathrm{g}$ $\mathrm{Fe} / \mathrm{mL}$, the cell survival rate of $\mathrm{Fe}_{3} \mathrm{O}_{4}$-treated group was still $80 \%$. This was similar with the outcomes from inverted microscopy and demonstrated that $\mathrm{Fe}_{3} \mathrm{O}_{4}$ MNPs had less cytotoxicity in vitro.

\section{MN Results of $\mathrm{Fe}_{3} \mathrm{O}_{4}$ MNPs}

In our study, the MN formation rates of 5.00, 3.75, 2.50 and $1.25 \mathrm{~g} / \mathrm{kg}$ experimental groups, negative control group and positive control group were $2.56 \%$, $2.41 \%$, $2.29 \%$, $2.1 \%$, $2.09 \%$ and 26.65\%o, respectively (Figure 7), showing a significant difference between the experimental groups and

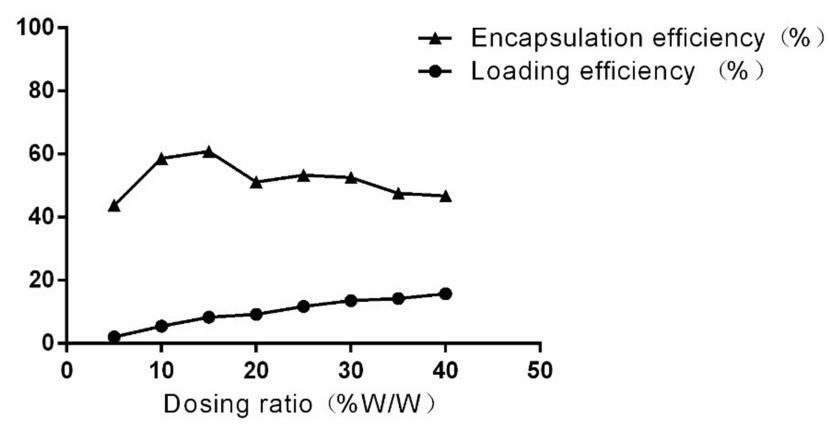

Figure 3 Encapsulation efficiency and drug loading efficiency of MTX detected by UV-VIS-NIR spectrophotometer.

Note: When drug loading efficiency was 15\%, drug encapsulation efficiency reached the maximum value of $60.9 \%$. 
Table I Encapsulation Efficiency and Drug Loading Efficiency of MTX

\begin{tabular}{|l|l|l|}
\hline $\begin{array}{l}\text { Dosing Ratio } \\
\text { (\%W/W) }\end{array}$ & $\begin{array}{l}\text { Loading } \\
\text { Efficiency (\%) }\end{array}$ & $\begin{array}{l}\text { Encapsulation } \\
\text { Efficiency (\%) }\end{array}$ \\
\hline 5 & $2.15 \pm 0.1$ & 43.9 \\
10 & $5.55 \pm 0.17$ & 58.7 \\
15 & $8.37 \pm 0.15$ & 60.9 \\
20 & $9.32 \pm 0.21$ & 51.2 \\
\hline
\end{tabular}

Notes: $\mathrm{n}=3$, mean \pm standard deviation

the positive control group $(P<0.05)$. But $\mathrm{MN}$ formation rates at different doses of experimental groups showed no statistical difference compared with the negative control group $(P>0.05)$. These results indicated that $\mathrm{Fe}_{3} \mathrm{O}_{4} \mathrm{MNPs}$ as our carrier were not genotoxic.

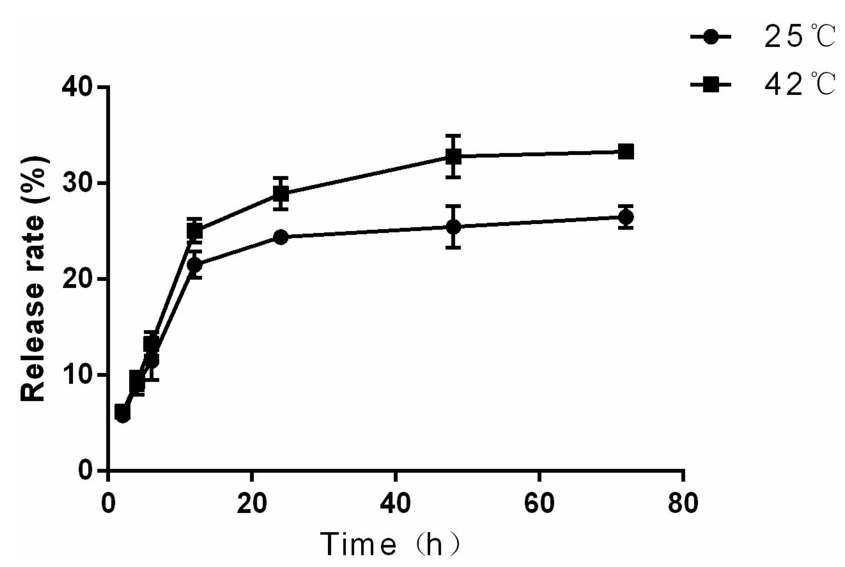

Figure 4 Drug release curve of $\mathrm{Fe}_{3} \mathrm{O}_{4} @ M T X$ MNPs at different temperatures. Note: The drug release occurred in two phases: an initial burst release within 12 hrs and a sustained release after that.

Abbreviation: MNPs, magnetic nanoparticles.

\section{Acute Toxicity in Mice $\mathrm{Fe}_{3} \mathrm{O}_{4} @ M T X$ MNPs}

Some behavioral changes such as crouching, apathy and slow response to external stimulus were observed among some animals immediately after $\mathrm{Fe}_{3} \mathrm{O}_{4} @$ MTX MNPs injection; most of them resumed normal activity rapidly. The deaths of mice in each group occurred during these 14 days after administration (Table 2). SPSS were used to calculate the $\mathrm{LD}_{50}$ of $\mathrm{Fe}_{3} \mathrm{O}_{4} @ \mathrm{MTX}$ MNPs, which evaluated short-term toxicity after intraperitoneal administration. The $\mathrm{LD}_{50}$ of the complex nano drug-loading system to the mice was $8.579 \mathrm{~g} /$ $\mathrm{kg}$, and its 95\% confidence interval (CI) was 6.300-12.333 g/ $\mathrm{kg}$ from the acute toxicological study.

\section{In vitro Evaluation of the Efficacy of $\mathrm{Fe}_{3} \mathrm{O}_{4}$ @MTX MNPs on OCl-LY8 PCNSL Cells}

\section{Perls Stain}

The stained OCI-LY18 cells were observed under an inverted microscope $(10 \times 100)$. It was shown that iron reacted with potassium ferrocyanide to form iron ferrocyanide precipitated in the intracellular iron, which manifested that $\mathrm{Fe}_{3} \mathrm{O}_{4} @ \mathrm{MTX}$ complex MNPs could enter OCI-LY18 cells easily (Figure 8).

\section{Apoptosis Assay}

The rate of apoptotic OCI-LY18 cells after $48 \mathrm{hrs}$ of treatment is shown in Figure 9. It showed that the main function of our therapy was to induce apoptosis of OCILY18 cells in vitro. The percentages of apoptotic cells in control group were $7.21 \pm 3.68 \%$, while the percentages of apoptotic cells after treatment with $\mathrm{Fe}_{3} \mathrm{O}_{4} \mathrm{MNPs}, \mathrm{Fe}_{3} \mathrm{O}_{4}$ MNPs with hyperthermia, MTX, $\mathrm{Fe}_{3} \mathrm{O}_{4} @$ MTX MNPs and $\mathrm{Fe}_{3} \mathrm{O}_{4} @ \mathrm{MTX}$ MNPs with hyperthermia were 13.87

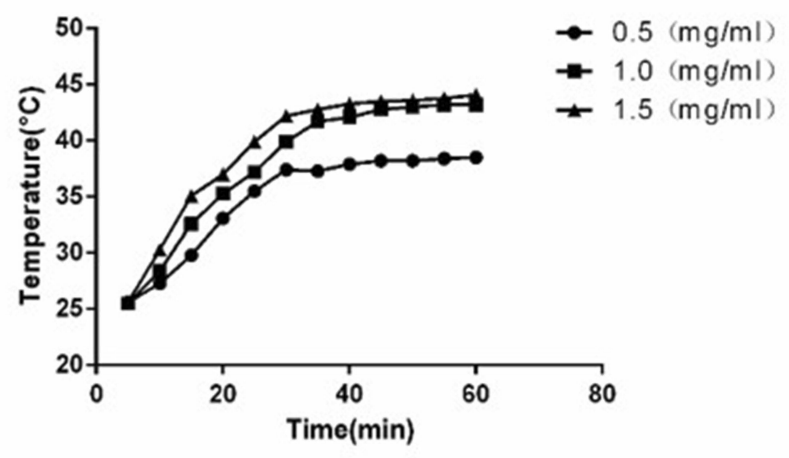

A

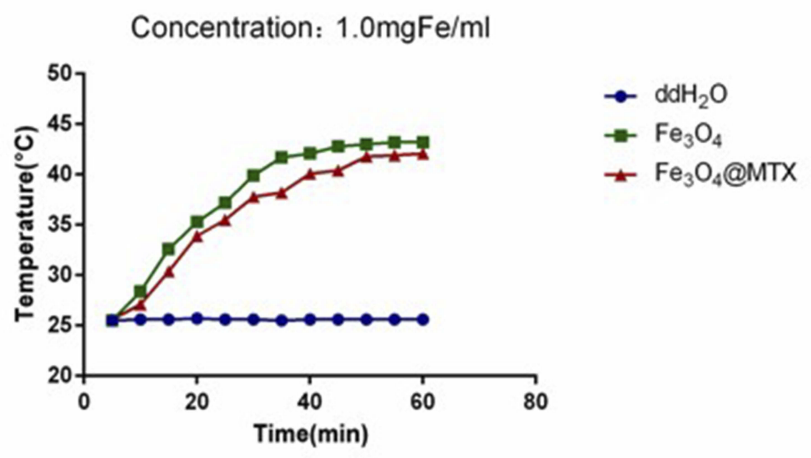

B

Figure 5 Heating capacity of MNPs at alternating magnetic field (A) Heating curve of $\mathrm{Fe}_{3} \mathrm{O}_{4} \mathrm{MNPs}(0.5,1.0,1.5 \mathrm{mg} \mathrm{Fe} / \mathrm{mL})$; (B) Heating curve of Fe $\mathrm{O}_{4} @ M T X$ MNPs compared with $\mathrm{Fe}_{3} \mathrm{O}_{4}$ MNPs and $\mathrm{ddH}_{2} \mathrm{O}(\mathrm{I} .0 \mathrm{mg} \mathrm{Fe} / \mathrm{mL})$.

Abbreviation: MNPs, magnetic nanoparticles. 
$\pm 1.36 \%, 31.35 \pm 3.02 \%, 28.51 \pm 0.99 \%, 17.22 \pm 2.71 \%$ and $52.00 \pm 5.50 \%$, respectively. The function of hyperthermia at temperatures over $42^{\circ} \mathrm{C}$ is to cause inhibition of cellular enzymes and cell damage most probably through the process of apoptosis. ${ }^{26}$ In our research, the magnetic nanoparticle hyperthermia groups could induce apoptosis even in the absence of MTX. Induction of apoptosis after treatment with $\mathrm{Fe}_{3} \mathrm{O}_{4}$ MNPs combined with hyperthermia was considerably greater than in the $\mathrm{Fe}_{3} \mathrm{O}_{4}$ MNPs group $(P<0.01)$ and control group $(P<0.01)$. At the same time, apoptosis rate in $\mathrm{Fe}_{3} \mathrm{O}_{4} @ \mathrm{MTX}$ MNPs combined with hyperthermia group was considerably greater than in the $\mathrm{Fe}_{3} \mathrm{O}_{4} @$ MTX MNPs group $(P<0.01)$ and MTX group $(P<0.01)$. These results suggested that when combined with hyperthermia, $\mathrm{Fe}_{3} \mathrm{O}_{4} @$ MTX MNPs were more effective in terms of inhibiting cell proliferation.

\section{qPCR and Western Blot}

Transcription and translation of apoptosis-related gene Caspase-3, Bax and Bcl-2 were detected by qPCR and Western blot after OCI-LY18 cells of each experimental group were treated in the incubator for $48 \mathrm{hrs}$. The
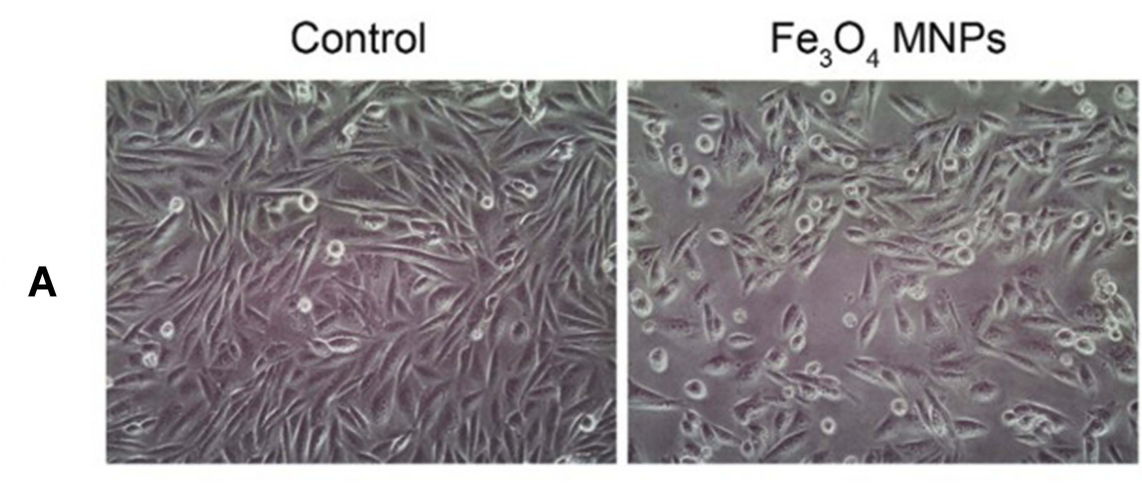

\section{$\mathrm{Fe}_{3} \mathrm{O}_{4} @ M T X$ MNPs}
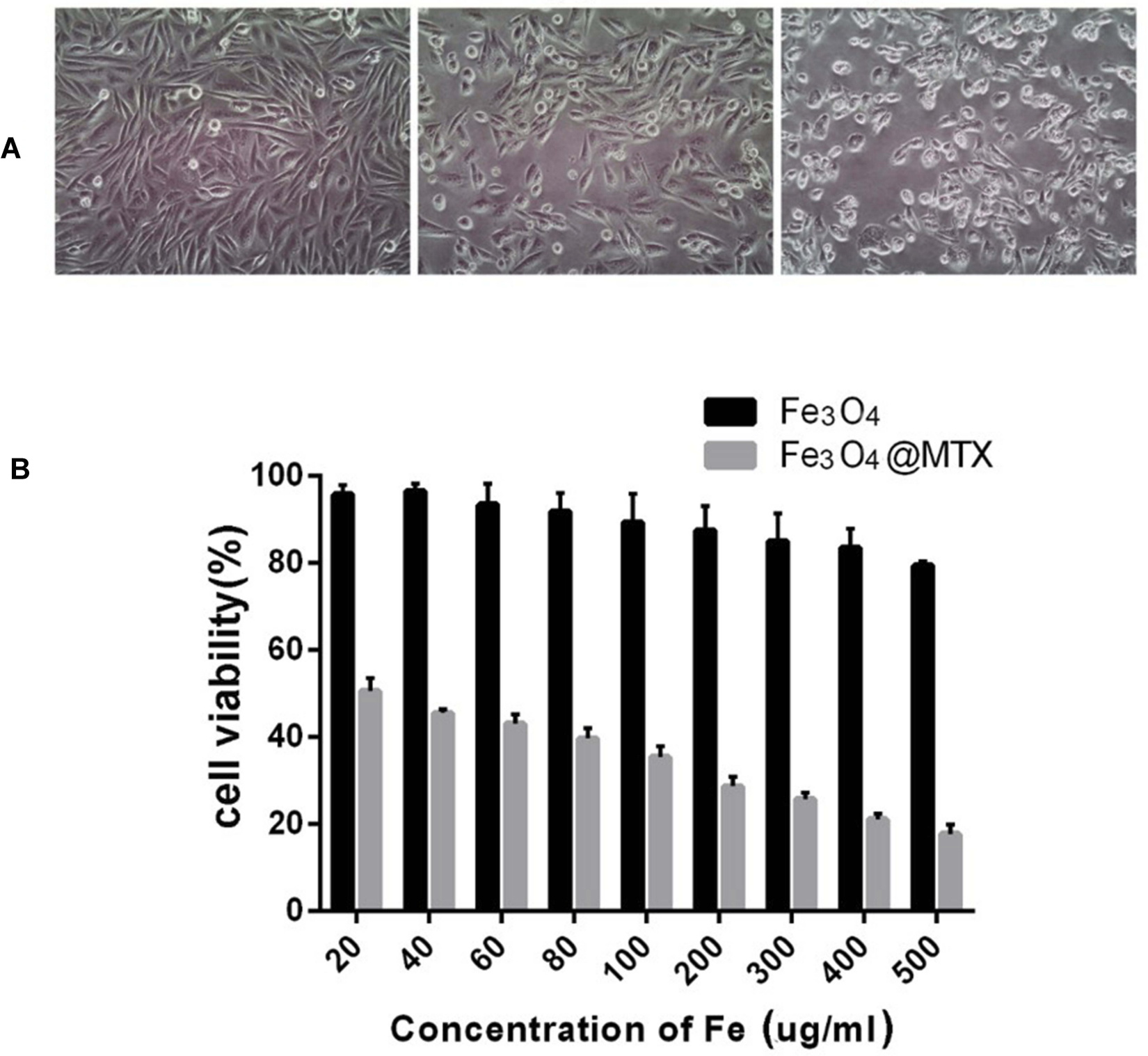

Figure 6 Biocompatibility of $\mathrm{Fe}_{3} \mathrm{O}_{4}$ MNPs carrier (A) Inverted microscopy images of $3 \mathrm{~T} 3$ cells incubated with $\mathrm{Fe}_{3} \mathrm{O}_{4} \mathrm{MNPs}$ and $\mathrm{Fe} \mathrm{O}_{3} \mathrm{O}_{4} @ M T X$ MNPs; $(\mathbf{B})$ CCK-8 assay of $\mathrm{Fe}_{3} \mathrm{O}_{4}$ MNPs and $\mathrm{Fe}_{3} \mathrm{O}_{4} @ M T X$ MNPs.

Abbreviations: MNPs, magnetic nanoparticles; CCK-8, cell counting kit-8. 


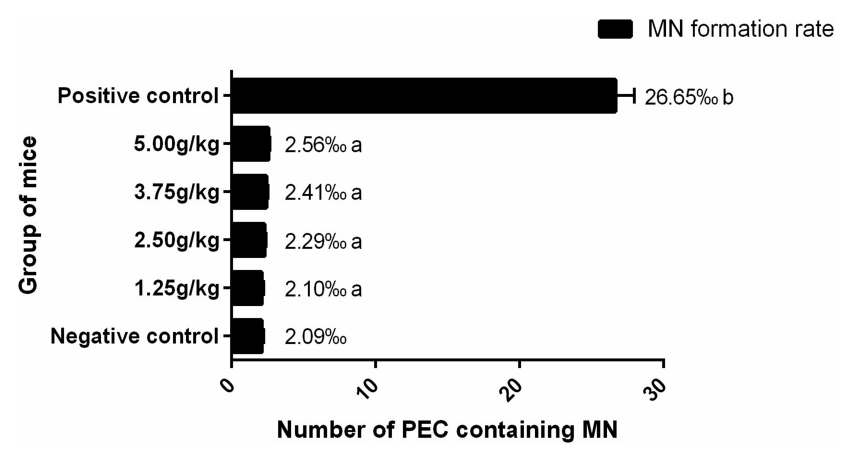

Figure 7 Genotoxicity of $\mathrm{Fe}_{3} \mathrm{O}_{4}$ MNPs carrier.

Notes: $\mathrm{n}=10$. ${ }^{\mathrm{a}} \mathrm{P}>0.05, \mathrm{MN}$ formation rates of $\mathrm{Fe}_{3} \mathrm{O}_{4} \mathrm{MNPs}$ groups compared with negative control; ' $\mathrm{P}<0.05, \mathrm{MN}$ formation rates between $\mathrm{Fe}_{3} \mathrm{O}_{4} \mathrm{MNPs}$ groups and positive control.

Abbreviations: MN, micronucleus; PEC, polychromatic erythrocytes, MNPs, magnetic nanoparticles.

transcription of Caspase- 3 gene in the $\mathrm{Fe}_{3} \mathrm{O}_{4} @ \mathrm{MTX}$ MNPs group were enhanced by hyperthermia which were significantly higher than that of $\mathrm{Fe}_{3} \mathrm{O}_{4} \mathrm{MNPs}$ hyperthermia group $(P<0.05), \mathrm{Fe}_{3} \mathrm{O}_{4} @$ MTX MNPs non-hyperthermia group $(P<0.01)$ and MTX chemotherapy group $(P<0.01)$. At the same time, the transcription of Bax gene in the $\mathrm{Fe}_{3}$ $\mathrm{O}_{4} @$ MTX MNPs group were enhanced by hyperthermia which were significantly higher than that of $\mathrm{Fe}_{3} \mathrm{O}_{4} @ \mathrm{MTX}$ MNPs non-hyperthermia group $(P<0.05)$ and MTX chemotherapy group $(P<0.01)$. The transcription of Bcl-2 gene in the $\mathrm{Fe}_{3} \mathrm{O}_{4} @$ MTX MNPs was inhibited by hyperthermia which were significantly lower than that of $\mathrm{Fe}_{3} \mathrm{O}_{4} @$ MTX MNPs non-hyperthermia group $(P<0.01)$ and MTX chemotherapy group $(P<0.01)$. In addition, the transcription apoptosis-inducing gene Caspase-3 and Bax in the $\mathrm{Fe}_{3} \mathrm{O}_{4}$ MNPs with hyperthermia group were higher than that of $\mathrm{Fe}_{3} \mathrm{O}_{4}$ MNPs non-hyperthermia group (Caspase-3 gene, $P<0.05$; Bax gene, $P=0.079$ ), and

Table 2 Acute Toxicity Test for Detecting $\mathrm{LD}_{50}$ of $\mathrm{Fe}_{3} \mathrm{O}_{4} @ M T X$ MNPs

\begin{tabular}{|l|l|l|l|}
\hline Group & Dosage & $\mathbf{n}$ & Death Number \\
\hline 1 & 1.77 & 10 & 0 \\
2 & 2.51 & 10 & 0 \\
3 & 3.54 & 10 & 2 \\
4 & 5.00 & 10 & 3 \\
5 & 7.06 & 10 & 3 \\
6 & 9.98 & 10 & 4 \\
7 & 14.09 & 10 & 8 \\
8 & 19.89 & 10 & 10 \\
\hline
\end{tabular}

Notes: $\mathrm{LD}_{50}$ of $\mathrm{Fe}_{3} \mathrm{O}_{4} @ M T X$ MNPs was 8.579 g/kg ( $\left.95 \% \mathrm{Cl}: 6.300-12.333 \mathrm{~g} / \mathrm{kg}\right)$. Abbreviations: $\mathrm{LD}_{50}$, median lethal dose; $\mathrm{Cl}$, confidence interval; MNPs, magnetic nanoparticles. apoptosis-inhibiting gene $\mathrm{Bcl}-2$ in the $\mathrm{Fe}_{3} \mathrm{O}_{4}$ MNPs hyperthermia group were significantly lower than that of $\mathrm{Fe}_{3} \mathrm{O}_{4}$ MNPs non-hyperthermia group $(P<0.01)$, as Figure 10A. The protein expressions of Caspase-3, Bax and Bcl-2 in OCI-LY18 cells treated with different groups for $48 \mathrm{hrs}$ were detected by Western blotting. Figure 10B shows that $\mathrm{Fe}_{3} \mathrm{O}_{4} @$ MTX MNPs with hyperthermia could significantly upregulate the expression levels of Caspase-3, Bax, and downregulate Bcl-2. These results are consistent with the findings at gene level.

\section{In vivo Evaluation of the Efficacy of $\mathrm{Fe}_{3} \mathrm{O}_{4}$ @MTX MNPs on Intracranial Tumor BALB/c-Nude Mice Model $M R I$ and H\&E Stain}

MRI was performed 12 days after tumor implantation, and the results showed that the modeling was successful, and the mice with tumor in diameter about $0.5 \mathrm{~cm}$ was selected for treatment. After administration, MRI showed a low-signal region where MNPs accumulated in tumor location after a strong magnet was placed on the right side of the mice brain (Figure 11A). As Figure 11B and C, the tumor volume of the $\mathrm{Fe}_{3} \mathrm{O}_{4}+\mathrm{MTX}+\mathrm{H}$ group was significantly lower than that of the MTX group $(P<0.05)$. The tumor volume of the $\mathrm{Fe}_{3} \mathrm{O}_{4}+\mathrm{H}$ group was significantly lower than in the $\mathrm{Fe}_{3} \mathrm{O}_{4}$ group $(P<0.05)$. The result indicated that $\mathrm{Fe}_{3} \mathrm{O}_{4} @ \mathrm{MTX}$ MNPs with hyperthermia could significantly reduce tumor volume, and thus inhibit the tumor progression.

Brain tissues of each group were taken and fixed by formalin immediately after perfusion, and the results were observed after H\&E staining (Figure 12). The number of tumor cells in the combined thermochemotherapy $\mathrm{Fe}_{3} \mathrm{O}_{4} @ \mathrm{MTX}$ MNPs group was significantly reduced compared with the single chemotherapy group and replaced by cell interstitial, which was consistent with the imaging results.

\section{qPCR and Western Blot of Tumor Tissues}

The transcription of apoptosis-inducing genes Caspase- 3 and $\mathrm{Bax}$ in $\mathrm{Fe}_{3} \mathrm{O}_{4} @ \mathrm{MTX}+\mathrm{H}$ group were significantly higher than in MTX group, $\mathrm{Fe}_{3} \mathrm{O}_{4} @$ MTX group and $\mathrm{Fe}_{3}$ $\mathrm{O}_{4}+\mathrm{H}$ group $(P<0.05)$. The transcription of Caspase- 3 in $\mathrm{Fe}_{3} \mathrm{O}_{4}+\mathrm{H}$ group was also higher than in $\mathrm{Fe}_{3} \mathrm{O}_{4}$ group $(P=0.399)$ and Bax transcription level of the $\mathrm{Fe}_{3} \mathrm{O}_{4}+\mathrm{H}$ group was also increased compared with the $\mathrm{Fe}_{3} \mathrm{O}_{4}$ group $(P=0.506)$; the transcription of apoptosis-inhibiting gene $\mathrm{Bcl}-2$ in $\mathrm{Fe}_{3} \mathrm{O}_{4} @ \mathrm{MTX}+\mathrm{H}$ group was lower than in MTX 


\section{Blank}

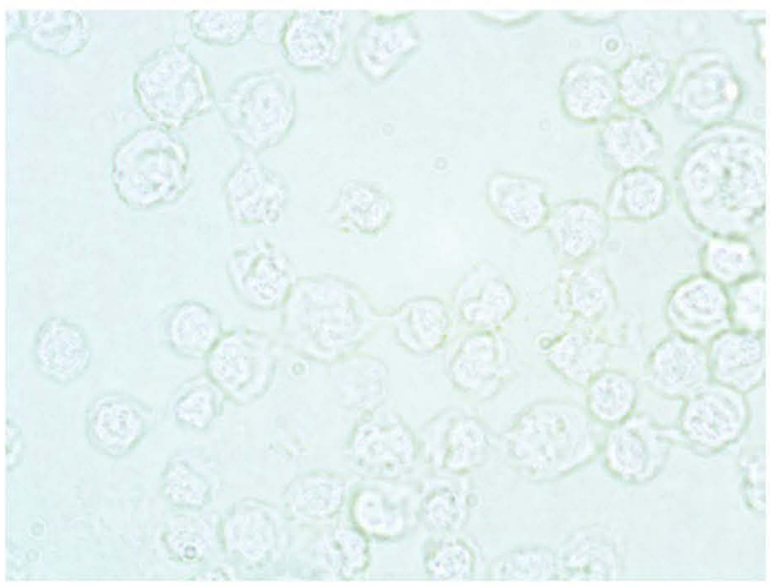

$1 \mathrm{~h}$

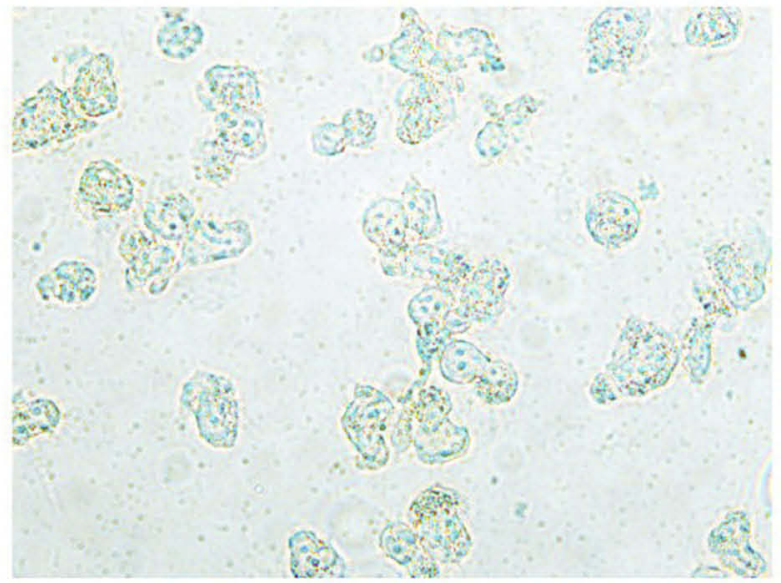

Figure 8 The labeling effect of $\mathrm{Fe}_{3} \mathrm{O}_{4} @ M T X$ MNPs on OCl-LYI8 cells by Perls. Note: $\mathrm{Fe}_{3} \mathrm{O}_{4} @ M T X$ MNPs could get into OCl-LYI8 cells, 10×100 magnification. Abbreviation: MNPs, magnetic nanoparticles.

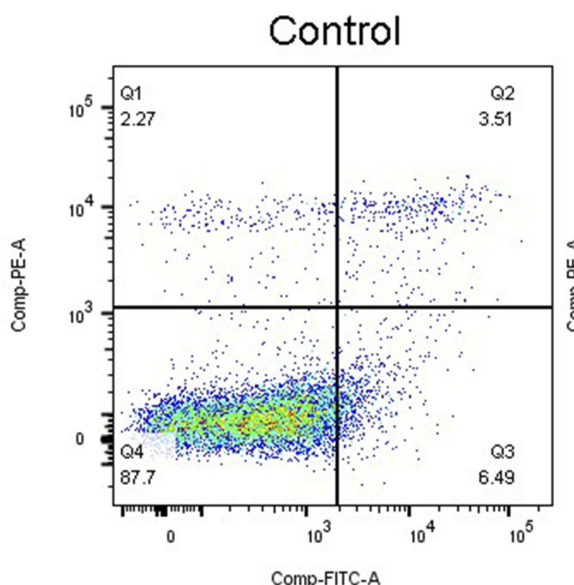

$\mathrm{Fe}_{3} \mathrm{O}_{4} @ \mathrm{MTX}$

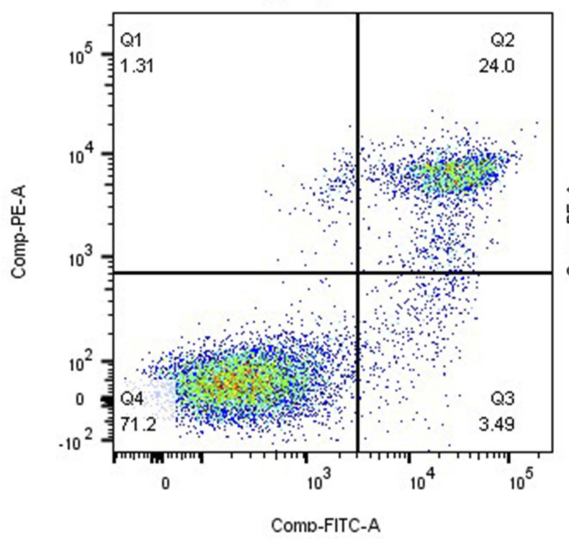

$\mathrm{Fe}_{3} \mathrm{O}_{4}$

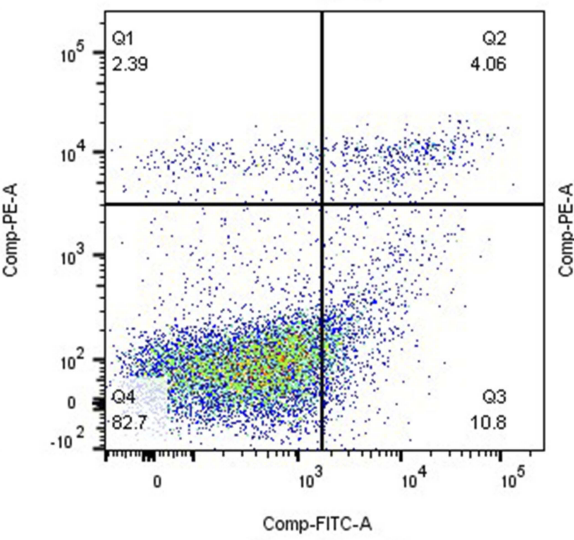

$\mathrm{Fe}_{3} \mathrm{O}_{4}+\mathrm{H}$

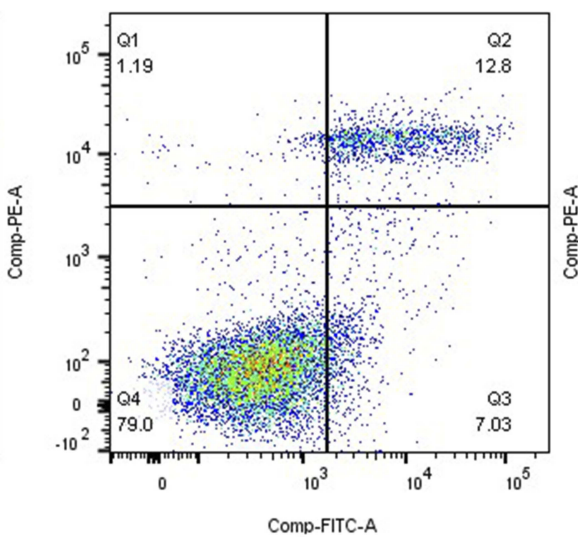

MTX

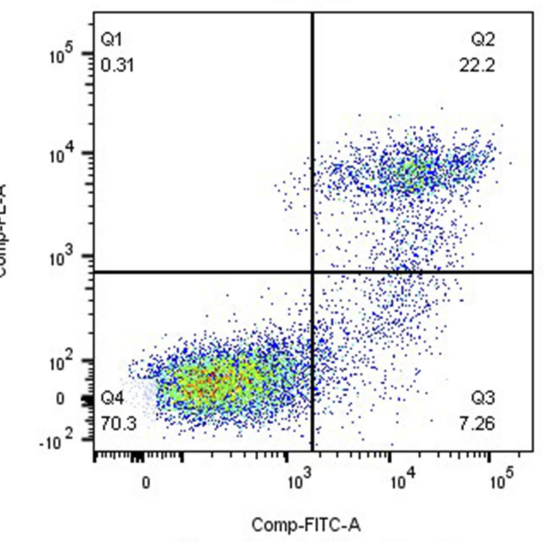

$\mathrm{Fe}_{3} \mathrm{O}_{4} @ \mathrm{MTX}+\mathrm{H}$

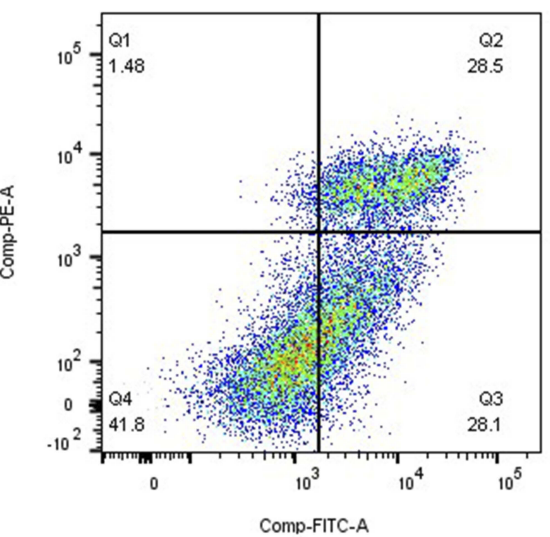

Figure 9 Apoptosis rate of $\mathrm{OCl}-\mathrm{LY} 18$ cells determined by flowcytometry.

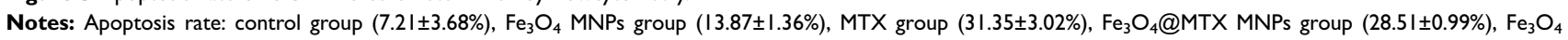
MNPs with hyperthermia group (I7.22 $\pm 2.71 \%), \mathrm{Fe}_{3} \mathrm{O}_{4} @ M T X$ MNPs with hyperthermia group $(52.00 \pm 5.50 \%)$. $P<0.0 \mathrm{I}, \mathrm{Fe}_{3} \mathrm{O}_{4}+\mathrm{H}_{\text {vs }} \mathrm{Control}$ and $\mathrm{FE}_{3} \mathrm{O} \mathrm{O}_{4}$ groups; $\mathrm{P}<0.0 \mathrm{I}, \mathrm{Fe} \mathrm{e}_{3}$ $\mathrm{O}_{4} @ M T X+\mathrm{H}$ vs MTX and $\mathrm{Fe}_{3} \mathrm{O}_{4} @ M T X$ groups.

Abbreviation: MNPs, magnetic nanoparticles. 

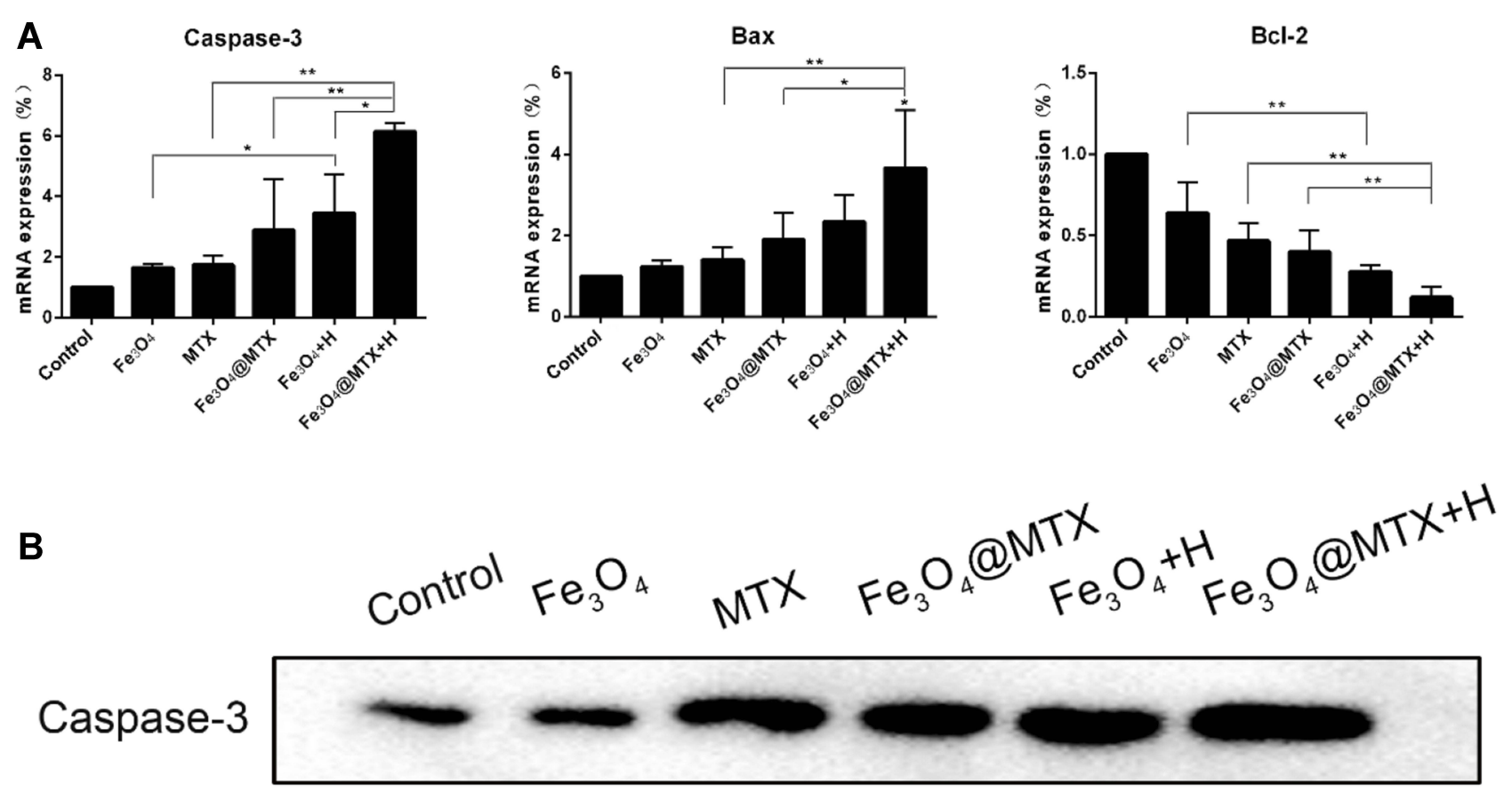

Bax

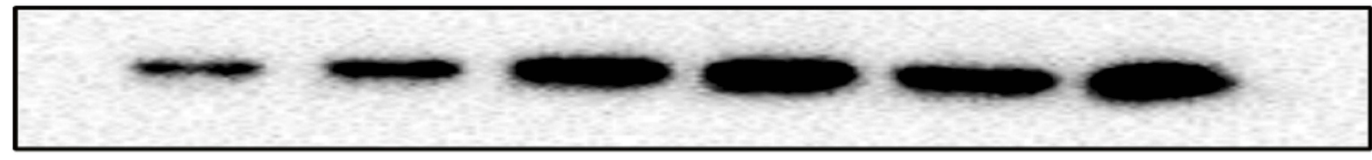

$\mathrm{BCl}-2$

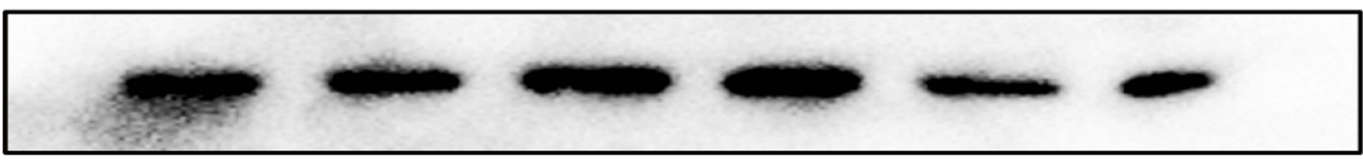

GAPDH

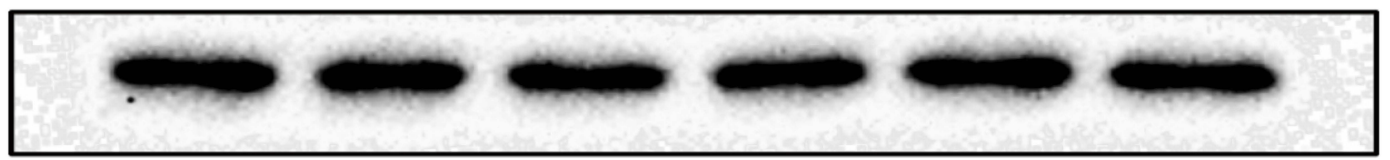

Figure 10 qPCR and Western blot analyses of OCI-LYI 8 cells after different treatments. (A) Transcription of Caspase-3, Bax and Bcl-2 genes were detected by qPCR; (B) Expression of Caspase-3, Bax and Bcl-2 proteins were detected by Western blot. Notes: $* \mathrm{P}<0.05 ; * * \mathrm{P}<0.01$.

group $(P=0.059)$; $\mathrm{Bcl}-2$ in $\mathrm{Fe}_{3} \mathrm{O}_{4}+\mathrm{H}$ group was also significantly lower than in $\mathrm{Fe}_{3} \mathrm{O}_{4}$ group $(P<0.05)$ (Figure 13A). The protein expressions of Caspase-3, Bax and $\mathrm{Bcl}-2$ in tumor tissues were examined by Western blot as shown in Figure 13B. Semi-quantitative results were basically consistent with qPCR results (Figure 13C). Caspase-3 and Bax were upregulated in $\mathrm{Fe}_{3} \mathrm{O}_{4} @ \mathrm{MTX}+\mathrm{H}$ group $(P<0.05)$, while $\mathrm{Bcl}-2$ were downregulated both in $\mathrm{Fe}_{3} \mathrm{O}_{4} @ \mathrm{MTX}+\mathrm{H}$ and $\mathrm{Fe}_{3} \mathrm{O}_{4}+\mathrm{H}$ groups $(P<0.05)$. The above findings in vivo were consistent with in vitro study, which indicated that $\mathrm{Fe}_{3} \mathrm{O}_{4} @$ MTX MNPs combined with hyperthermia could induce apoptosis of tumor cells better.

\section{Discussion}

Combination therapy is the most promising treatment method, aiming to improve efficacy and reduce the dosage of single drug. The application of traditional treatments for tumors has gradually shown many limitations. Magnetic fluid hyperthermia as a special physical way, which could increase the temperature above $42^{\circ} \mathrm{C}$ and targeted to various tumor cells and tissues, has gained more and more attention and recognition. ${ }^{18}$ 

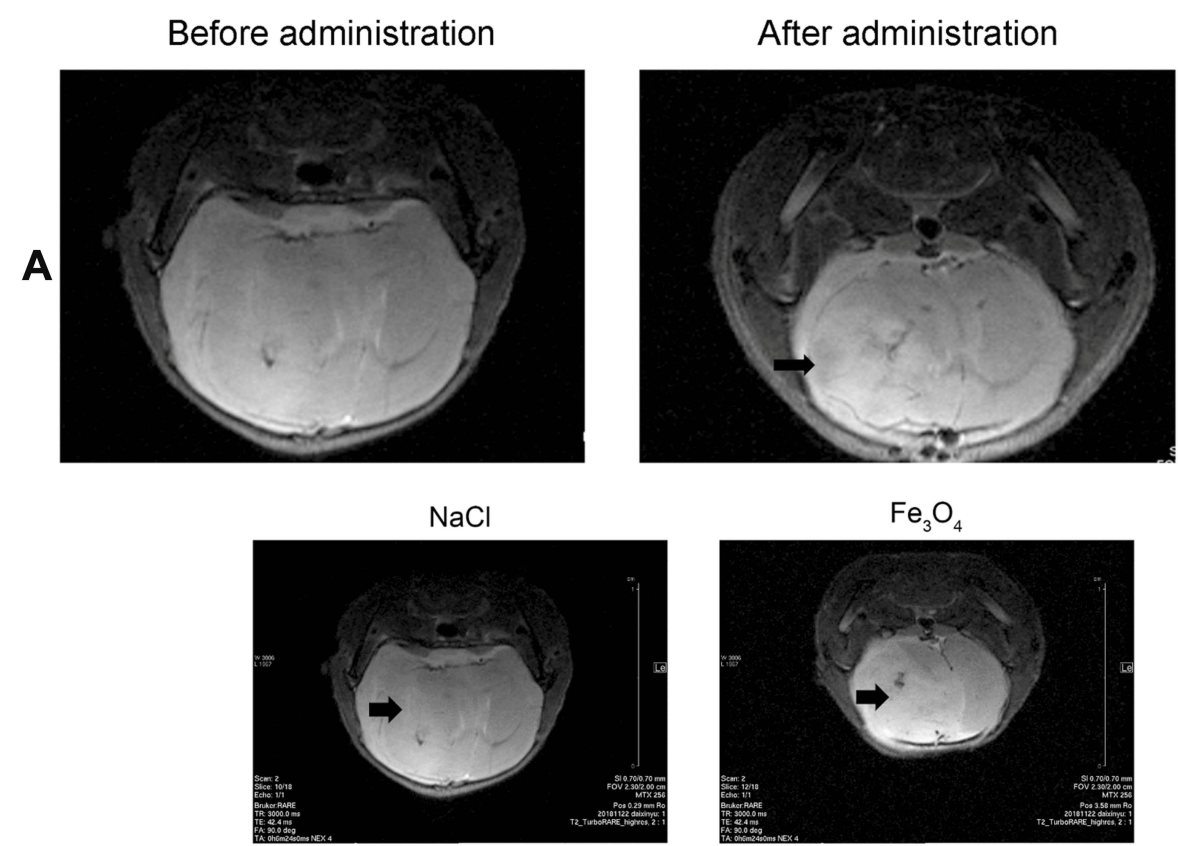

B

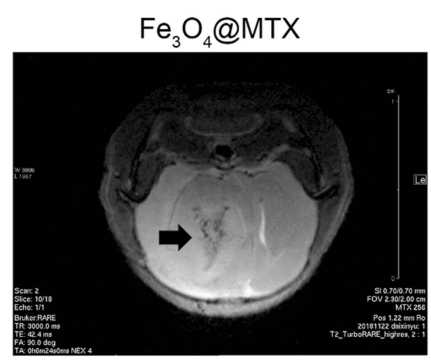

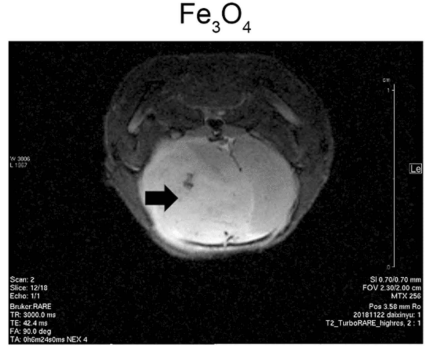

$\mathrm{Fe}_{3} \mathrm{O}_{4}+\mathrm{H}$

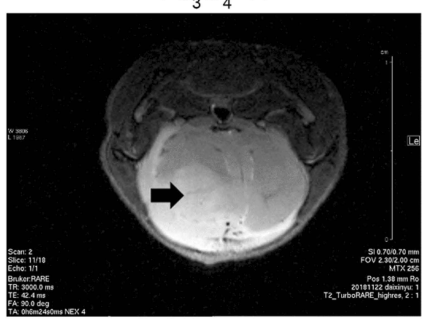

C
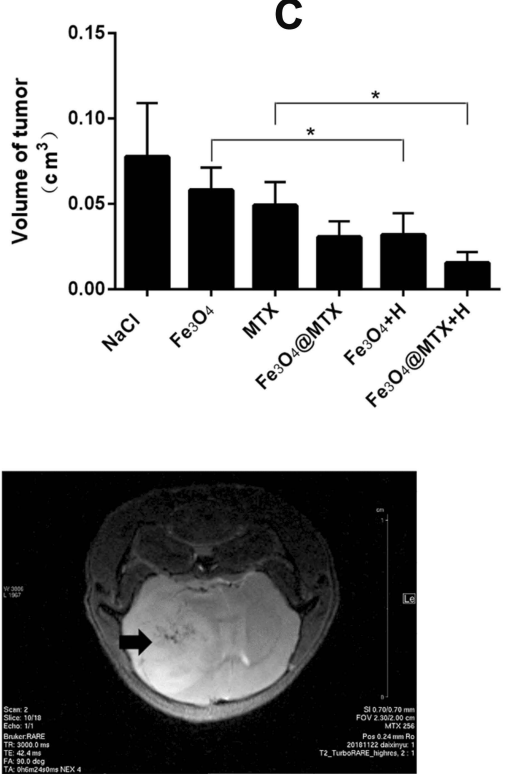

$\mathrm{Fe}_{3} \mathrm{O}_{4} @ \mathrm{MTX}+\mathrm{H}$

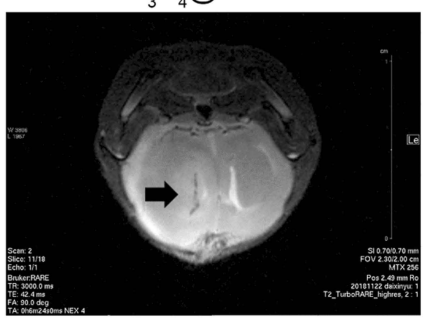

Figure I I MRI detection of targeting and treatment effect. (A) Low signal region showed that MNPs could concentrated at tumor site after the application of a magnet; (B) MRI images after different treatment effects; $(\mathbf{C})$ Volume of tumors in various treatment groups.

Notes: Low signal region indicated by the arrow in Figure IIA shows MNPs could target tumor tissues under the guidance of external magnetic field; High signal regions indicated by the arrows in Figure IIB show tumors after various treatments; * $\mathrm{P}<0.05$.

Abbreviation: MNPs, magnetic nanoparticles.

Superparamagnetic iron oxide nanoparticles have been widely used in imaging, drug delivery and heating, ${ }^{27,28}$ and their combination with surgery, radiotherapy, chemotherapy and even ultrasound ${ }^{29}$ has shown excellent outcomes in both in vitro and in vivo experiments on liver, ${ }^{30,31}$ breast, $^{32-35}$ colon $^{36-39}$ and brain cancers. ${ }^{40-43}$

In our study, we have developed water-dispersible superparamagnetic MTX loaded Pluronic F-127/OA-coated $\mathrm{Fe}_{3} \mathrm{O}_{4}$ MNPs, which had an average hydrated diameter of $113 \mathrm{~nm}$ (Figure 2B). Superparamagnetic properties of MNPs in various research were proven well after coated with kinds of materials, ${ }^{25,44}$ Figure $2 \mathrm{C}$ shows that remanence and coercivity of our nano drug-loading system $\mathrm{Fe}_{3} \mathrm{O}_{4} @$ MTX MNPs were zero. After sequential modification successfully, zeta potential of $\mathrm{Fe}_{3} \mathrm{O}_{4}$ MNPs $(-3.1 \mathrm{mV})$ was decreased to $-25.8 \mathrm{mV}$ of Pluronic F-127/OA-coated $\mathrm{Fe}_{3} \mathrm{O}_{4}$ MNPs in the neutral environment of $\mathrm{pH} 7.4$ (Figure 2D). Compared with our previous research of $\mathrm{Fe}_{3} \mathrm{O}_{4} @ \mathrm{Au}-\mathrm{C} 225$ MNPs $(11.1 \pm 1.8 \mathrm{mV}){ }^{45}$ the final $\mathrm{Fe}_{3} \mathrm{O}_{4} @$ MTX MNPs was negatively charged $(-22.2 \mathrm{mV})$, which may help to bind to positively charged cells. The maximum drug encapsulation efficiency was $60.9 \%$ when drug loading efficiency was 15\% (Figure 3 and Table 1); thus, $\mathrm{Fe}_{3} \mathrm{O}_{4} @$ MTX MNPs we used for subsequent treatment reduced the dose of MTX by about $40 \%$. Furthermore, the MTX release profiles showed a sustained release pattern and cumulative amount of MTX release was $26.3 \%$ at $25^{\circ} \mathrm{C}$ and reached $33.3 \%$ at $42^{\circ} \mathrm{C}$ in $72 \mathrm{hrs}$ after initial $12 \mathrm{hrs}$ which indicated that our formulation may extend the cycle time of MTX in body and improved treatment efficiency (Figure 4). Heating capacity of $\mathrm{Fe}_{3} \mathrm{O}_{4} @$ MTX MNPs was compared with $\mathrm{Fe}_{3} \mathrm{O}_{4}$ MNPs and $\mathrm{ddH}_{2} \mathrm{O}$ shown as in Figure 5. Biocompatibility of our $\mathrm{Fe}_{3} \mathrm{O}_{4} \mathrm{MNPs}$ carrier was tested in $3 \mathrm{~T} 3$ cells and KM mice and results showed less cell cytotoxicity and no genotoxic (Figures 6 and 7). The results of 


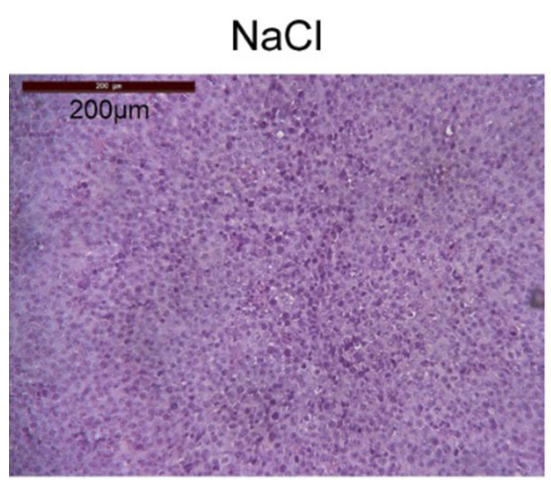

$\mathrm{Fe}_{3} \mathrm{O}_{4} @ \mathrm{MTX}$

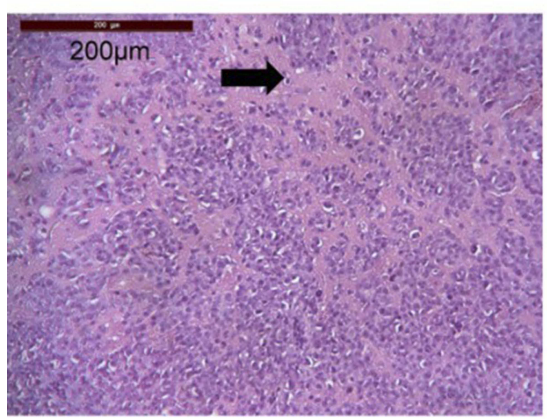

$\mathrm{Fe}_{3} \mathrm{O}_{4}$

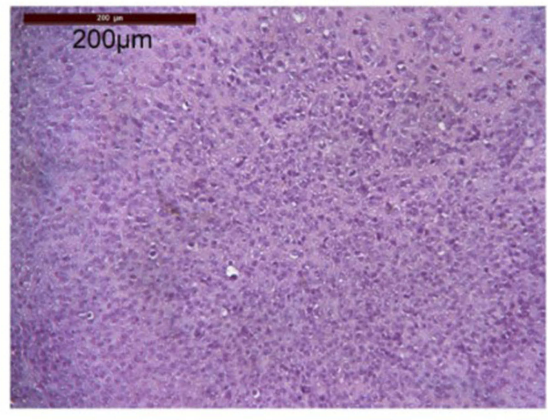

$\mathrm{Fe}_{3} \mathrm{O}_{4}+\mathrm{H}$

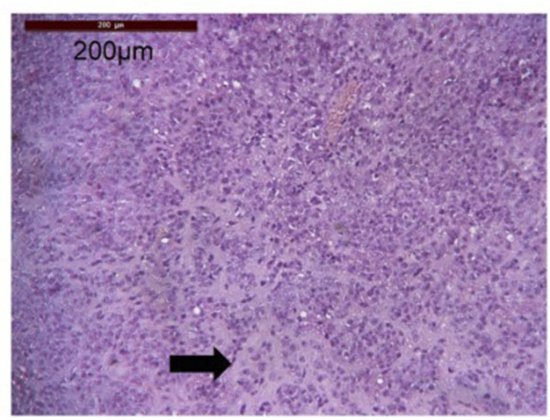

MTX

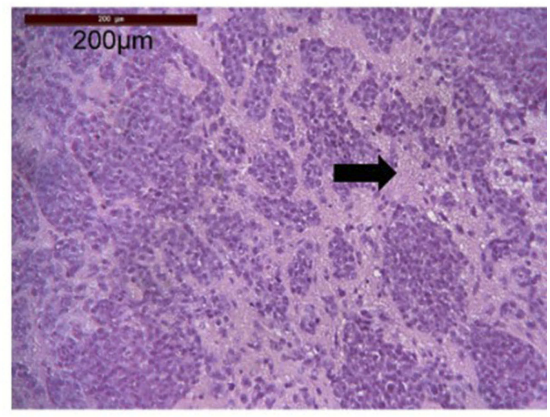

$\mathrm{Fe}_{3} \mathrm{O}_{4} @ \mathrm{MTX}+\mathrm{H}$

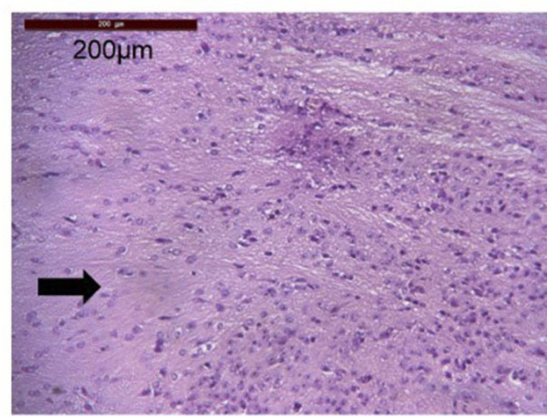

Figure 12 Histopathologic changes in various treatment groups.

Notes: Hematoxylin \& eosin staining, 10×100 magnification. The arrows illustrate tumor cells disappear at these areas.

acute toxicity test showed that $\mathrm{LD}_{50}$ of $\mathrm{Fe}_{3} \mathrm{O}_{4} @ \mathrm{MTX}$ MNPs drug-loading system was $8.579 \mathrm{~g} / \mathrm{kg}$ (Table 2); moreover, the safety range (95\% CI: $6.300-12.333 \mathrm{~g} / \mathrm{kg}$ ) was wider than $\mathrm{Fe}_{3}$ $\mathrm{O}_{4} @ \mathrm{Au}$ composite MNPs (95\% CI: 6.58-10.72 $\left.\mathrm{g} / \mathrm{kg}\right){ }^{25}$

In vitro, the cell apoptosis was measured by flow cytometry (Figure 9), and then qPCR and Western blot were performed to evaluate the molecular mechanisms of inducing apoptosis in OCI-LY18 cells and mice tissues (Figures 10 and 13). Tamas Vancsik et al indicated that hyperthermia could significantly reduce antiapoptotic XIAP, BCL-2 and BCL-XL and elevated proapoptotic BAX and PUMA, may further raise the sensitivity and/or reduce the therapeutic concentration and side effects of Dox. ${ }^{26}$ The results of Mantso et al showed that hyperthermia can exert therapeutic effectiveness against melanoma and colon carcinoma by inhibiting a number of critical cellular cascades including apoptosis, proliferation and DNA damage. ${ }^{46}$ The combined thermohyperthermia mediated by $\mathrm{Fe}_{3} \mathrm{O}_{4} @ \mathrm{MTX}$ MNPs in our study exhibited superior therapeutic efficacy on OCI-LY18 PNCSL cells by synergistic effects between chemotherapy and apoptosis, transcription and translation of apoptosis-inducing gene Caspase-3; Bax were significantly upregulated while apoptosis-inhibiting gene Bcl-2 were significantly inhibited in combined hyperthermia groups, indicating its excellent antitumor effect by inducing intrinsic apoptosis. After successful construction of mice intracranial tumor models, in vitro results indicated that hyperthermia can help inhibit tumor cells and thermochemotherapy of $\mathrm{Fe}_{3} \mathrm{O}_{4} @$ MTX $+\mathrm{H}$ group achieved significant therapeutic effects compared with other groups. Both MRI and pathology supported this conclusion (Figures 11 and 12). Furthermore, MRI in vivo show that the intensity and signal change rate of tumor tissues were decreased after tail vein injection of $\mathrm{Fe}_{3} \mathrm{O}_{4} @ \mathrm{Au}-\mathrm{C} 225$ composite targeted MNPs indicated by Ge et al. ${ }^{47}$ Our findings are similar with Ali Shakeri-Zadeh et $\mathrm{al}^{48}$ which states that MNPs could be guided by an external magnetic field and immobilized in the tumor as observed by the dark regions. Recently, some study indicated folateconjugated gold nanoparticles could increase the efficiency of cancer diagnosis and therapy, which inspires us to improve our modification on $\mathrm{Fe}_{3} \mathrm{O}_{4}$ nanoparticles to get better targeting. ${ }^{49}$ 

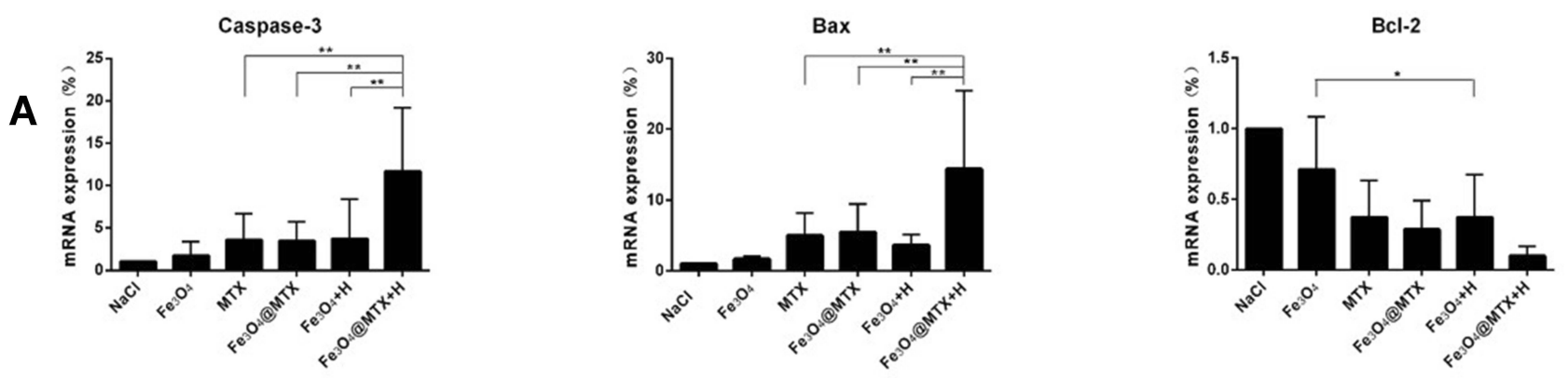

B

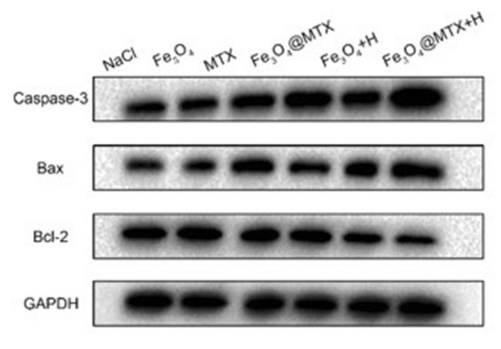

C

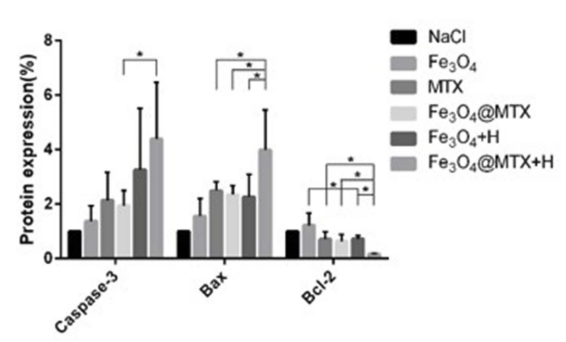

Figure 13 qPCR and Western blot analyses of tumor tissues after different treatments. (A) Transcription of Caspase-3, Bax and Bcl-2 genes were detected by qPCR; (B) Expression of Caspase-3, Bax and Bcl-2 proteins were detected by Western blot; (C) Semi-quantitative results of Caspase-3, Bax and Bcl-2 proteins.

Notes: $* \mathrm{P}<0.05$; $* * \mathrm{P}<0.01$.

\section{Conclusion}

In summary, we have successfully constructed and characterized $\mathrm{Fe}_{3} \mathrm{O}_{4} @$ MTX nano drug-loading system which could combine efficiently magnetic targeting, magnetic hyperthermia and chemotherapy into a whole. In addition, the combined effect could significantly improve the treatment effect, while reducing the use of chemotherapy drugs to avoid side effects. Finally, we conducted a preliminary exploration of the feasibility and possible mechanisms of inducing tumor apoptosis. In addition, we have performed proteomics to detect new possible proteins and acetylation sites in the MTX single chemotherapy group and $\mathrm{Fe}_{3} \mathrm{O}_{4} @ \mathrm{MTX}+\mathrm{H}$ thermochemotherapy group, and further optimize the hyperthermia conditions to explore whether the combined hyperthermia could stably inhibit the MTX key enzyme dihydrofolate reductase (DHRF) to solve the drug tolerance problems.

\section{Acknowledgments}

This work was supported by the National Natural Science Foundation of China (grant numbers: 81301313; 81600159), the Natural Science Foundation of Jiangsu Province (grant numbers: BK20131015; BK20141015), Jiangsu Provincial College Students' Practical Innovation Training Program (grant number: 201410312015Z), Nanjing Developing Project of Medical Science (grant number: YKK13174) and
Talent Plan of Jiangsu Cancer Hospital, "Six Talents Peak" High-Level Talents Project of Jiangsu Province (grant number: 2016-WSN-080), "333 High-Level Talent Training Project" of Jingsu Province (grant number: LGY2016019), and "Science and Education Invigorate Health Project" of Jingsu Province (grant number: QNRC2016677).

\section{Disclosure}

The authors declare no conflicts of interest in this work.

\section{References}

1. Soussain C, Choquet S, Blonski M, et al. Ibrutinib monotherapy for relapse or refractory primary CNS lymphoma and primary vitreoretinal lymphoma: final analysis of the phase II 'proof-of-concept' iLOC study by the Lymphoma study association (LYSA) and the French oculo-cerebral lymphoma (LOC) network. Eur $J$ Cancer. 2019;117:121-130. doi:10.1016/j.ejca.2019.05.024

2. Korfel A, Schlegel U. Diagnosis and treatment of primary CNS lymphoma. Nat Rev Neurol. 2013;9(6):317. doi:10.1038/nrneurol.2013.83

3. Citterio G, Calimeri T, Ajm F. Challenges and prospects in the diagnosis and treatment of primary central nervous system lymphoma. Expert Rev Neurother. 2018;18(5):1-15. doi:10.1080/ 14737175.2018.1462700

4. Braggio E, Van Wier S, Ojha J, et al. Genome-wide analysis uncovers novel recurrent alterations in primary central nervous system lymphomas. Clin Cancer Res. 2015;21(17):3986-3994. doi:10.1158/ 1078-0432.CCR-14-2116

5. Holdhoff M, Ambady P, Abdelaziz A, et al. High-dose methotrexate with or without rituximab in newly diagnosed primary CNS lymphoma. Neurology. 2014;83(3):235. doi:10.1212/WNL.0000000000000593 
6. Jara H. Primary central nervous system lymphoma: lessons and opportunities from 2 decades of CT and PET/CT. Radiology. 2019;292:191147.

7. Pentsova E, Deangelis LM, Omuro A. Methotrexate re-challenge for recurrent primary central nervous system lymphoma. J Neurooncol. 2014;117(1):161-165. doi:10.1007/s11060-014-1370-0

8. Pourtalebi JL, Mohammadi-Samani S, Heidari R, et al. In vitro- and in vivo evaluation of methotrexate-loaded hydrogel nanoparticles intended to treat primary CNS lymphoma via intranasal administration. J Pharm Pharm Sci. 2018;21(1):305-317. doi:10.18433/jpps29496

9. Abrey LE, Yahalom J, DeAngelis LM. Treatment for primary CNS lymphoma: the next step. J Clin Oncol. 2000;18:3144-3150. doi:10.1200/JCO.2000.18.17.3144

10. Batchelor TT. Primary central nervous system lymphoma: a curable disease. Hematol Oncol. 2019;15-18. doi:10.1002/hon.2598

11. Ferreri A, Cwynarski K, Pulczynski E, et al. Whole-brain radiotherapy or autologous stem-cell transplantation as consolidation strategies after high-dose methotrexate-based chemoimmunotherapy in patients with primary CNS lymphoma: results of the second randomisation of the International Extranodal Lymphoma Study Group-32 phase 2 trial. Lancet Haematol. 2017;4(11):e510-e523. doi:10.1016/ S2352-3026(17)30174-6

12. Fang C, Veiseh O, Kievit F, et al. Functionalization of iron oxide magnetic nanoparticles with targeting ligands: their physicochemical properties and in vivo behavior. Nanomedicine (Lond). 2010;5:1357-1369. doi:10.2217/nnm.10.55

13. Kossatz S, Grandke J, Couleaud P, et al. Efficient treatment of breast cancer xenografts with multifunctionalized iron oxide nanoparticles combining magnetic hyperthermia and anti-cancer drug delivery. Breast Cancer Res. 2015;17:66. doi:10.1186/s13058-015-0576-1

14. Shen B, Ma Y, Yu S, Ji. C. Smart multifunctional magnetic nanoparticle-based drug delivery system for cancer thermo-chemotherapy and intracellular imaging. ACS Appl Mater Interfaces. 2016;8(37):24502-245028. doi:10.1021/acsami.6b09772

15. Glassell M, Robles J, Das R, et al. Exchange-coupled $\mathrm{Fe}_{3} \mathrm{O}_{4} / \mathrm{CoFe}_{2}$ $\mathrm{O}_{4}$ nanoparticles for advanced magnetic hyperthermia. APS Meeting Abstracts, New Orleans, Louisiana; 2017.

16. Kandasamy G, Sudame A, Luthra T, et al. Functionalized hydrophilic superparamagnetic iron oxide nanoparticles for magnetic fluid hyperthermia application in liver cancer treatment. ACS Omega. 2018;3:3991-4005. doi:10.1021/acsomega.8b00207

17. Gresits I, Thuróczy G, Sági O, Gyüre-Garami B, Márkus BG, Simon F. Non-calorimetric determination of absorbed power during magnetic nanoparticle based hyperthermia. Sci Rep. 2018;8(1):12667. doi:10.1038/s41598-018-30981-x

18. Dadfar SM, Roemhild K, Drude NI, et al. Iron oxide nanoparticles: diagnostic, therapeutic and theranostic applications. Adv Drug Deliv Rev. 2019;138:302-325. doi:10.1016/j.addr.2019.01.005

19. Hervault A, Thanh NTK. Magnetic nanoparticle-based therapeutic agents for thermo-chemotherapy treatment of cancer. Nanoscale. 2014;6:11553-11573. doi:10.1039/C4NR03482A

20. Spirou SV, Costa Lima SA, Bouziotis P, et al. Recommendations for in vitro and in vivo testing of magnetic nanoparticle hyperthermia combined with radiation therapy. Nanomaterials (Basel). 2018;8. doi:10.3390/nano8050306

21. Shen B, Ma Y, Yu S, et al. Smart multifunctional magnetic nanoparticle-based drug delivery system for cancer thermochemotherapy and intracellular imaging. ACS Appl Mater Interfaces. 2016;8:24502-24508. doi:10.1021/acsami.6b09772

22. Barick KC, Singh S, Bahadur D, Lawande MA, Patkar DP, Hassan PA. Carboxyl decorated Fe3O4 nanoparticles for MRI diagnosis and localized hyperthermia. $J$ Colloid Interface Sci. 2014;418:120-125. doi:10.1016/j.jcis.2013.11.076

23. Liang P-C, Chen Y-C, Chiang C-F, et al. Doxorubicin-modified magnetic nanoparticles as a drug delivery system for magnetic resonance imaging-monitoring magnet-enhancing tumor chemotherapy. Int J Nanomedicine. 2016;11:2021-2037. doi:10.2147/IJN.S94139
24. Hu Y, Meng L, Niu L, et al. Highly cross-linked and biocompatible polyphosphazene-coated superparamagnetic $\mathrm{Fe} 3 \mathrm{O} 4$ nanoparticles for magnetic resonance imaging. Langmuir. 2013;29:9156-9163. doi:10.1021/la402119s

25. Li Y, Liu J, Zhong Y, et al. Biocompatibility of Fe(3)O(4)@Au composite magnetic nanoparticles in vitro and in vivo. Int $J$ Nanomedicine. 2011;6:2805-2819. doi:10.2147/IJN.S24596

26. Vancsik T, Forika G, Balogh A, et al. Modulated electro-hyperthermia induced p53 driven apoptosis and cell cycle arrest additively support doxorubicin chemotherapy of colorectal cancer in vitro. Cancer Med. 2019. doi:10.1002/cam4.2330

27. Dulińska-Litewka J, Łazarczyk A, Hałubiec P, et al. Superparamagnetic iron oxide nanoparticles-current and prospective medical applications. Materials (Basel). 2019;12:undefined. doi:10.3390/ma12040617

28. Tay ZW, Chandrasekharan P, Chiu-Lam A, et al. Magnetic particle imaging-guided heating in vivo using gradient fields for arbitrary localization of magnetic hyperthermia therapy. ACS Nano. 2018;12:3699-3713. doi:10.1021/acsnano.8b00893

29. Shakeri-Zadeh A, Khoei S, Khoee S, et al. Combination of ultrasound and newly synthesized magnetic nanocapsules affects the temperature profile of $\mathrm{CT} 26$ tumors in BALB/c mice. $J$ Med Ultrason. 2015;42:9-16. doi:10.1007/s10396-014-0558-4

30. Cellai F, Munnia A, Viti J, et al. Magnetic hyperthermia and oxidative damage to DNA of human hepatocarcinoma cells. Int J Mol Sci. 2017;18:939. doi:10.3390/ijms18050939

31. Li W-S, Wang X-J, Zhang S, et al. Mild microwave activated, chemo-thermal combinational tumor therapy based on a targeted, thermal-sensitive and magnetic micelle. Biomaterials. 2017;131:36-46. doi:10.1016/j.biomaterials.2017.03.048

32. Du Y, Liu X, Liang Q, et al. Optimization and design of magnetic ferrite nanoparticles with uniform tumor distribution for highly sensitive MRI/MPI performance and improved magnetic hyperthermia therapy. Nano Lett. 2019;19:3618-3626. doi:10.1021/acs.nanolett.9b00630

33. Gao F, Xie W, Miao Y, et al. Magnetic hydrogel with optimally adaptive functions for breast cancer recurrence prevention. $A d v$ Healthc Mater;2019. e1900203. doi:10.1002/adhm.201900203

34. Hadi F, Tavakkol S, Laurent S, et al. Combinatorial effects of radiofrequency hyperthermia and radiotherapy in the presence of magneto-plasmonic nanoparticles on MCF-7 breast cancer cells. J Cell Physiol. 2019. doi:10.1002/jcp.28599

35. Yan H, Shang W, Sun X, et al. Neoadjuvant nano-photothermal therapy used before operation effectively assists in surgery for breast cancer. Nanoscale. 2019;11:706-716. doi:10.1039/C8NR 08109C

36. Lima SA, Gaspar A, Reis S, et al. Multifunctional nanospheres for co-delivery of methotrexate and mild hyperthermia to colon cancer cells. Mater Sci Eng C Mater Biol Appl. 2017;75:1420-1426. doi:10.1016/j.msec.2017.03.049

37. Asadi L, Shirvalilou S, Khoee S, et al. Cytotoxic effect of 5-Fluorouracil-loaded polymer-coated magnetite nanographene oxide combined with radiofrequency. Anticancer Agents Med Chem. 2018;18:1148-1155. doi:10.2174/1871520618666180404151218

38. Thirunavukkarasu GK, Cherukula K, Lee $\mathrm{H}$, et al. Magnetic field-inducible drug-eluting nanoparticles for image-guided thermo-chemotherapy. Biomaterials. 2018;180:240-252. doi:10.1016/j. biomaterials.2018.07.028

39. Lorente C, Cabeza L, Clares B, et al. Formulation and in vitro evaluation of magnetoliposomes as a potential nanotool in colorectal cancer therapy. Colloids Surf B Biointerfaces. 2018;171:553-565. doi:10.1016/j.colsurfb.2018.07.070

40. Carvalho SM, Leonel AG, Mansur AAP, et al. Bifunctional magnetopolymersomes of iron oxide nanoparticles and carboxymethylcellulose conjugated with doxorubicin for hyperthermo-chemotherapy of brain cancer cells. Biomater Sci. 2019;7:2102-2122. doi:10.1039/C8BM01528G 
41. Grauer O, Jaber M, Hess K, et al. Combined intracavitary thermotherapy with iron oxide nanoparticles and radiotherapy as local treatment modality in recurrent glioblastoma patients. J Neurooncol. 2019;141:83-94. doi:10.1007/s11060-018-03005-x

42. Pinel S, Thomas N, Boura C, et al. Approaches to physical stimulation of metallic nanoparticles for glioblastoma treatment. Adv Drug Deliv Rev. 2019;138:344-357. doi:10.1016/j.addr.2018.10.013

43. Tapeinos C, Marino A, Battaglini M, et al. Stimuli-responsive lipid-based magnetic nanovectors increase apoptosis in glioblastoma cells through synergic intracellular hyperthermia and chemotherapy. Nanoscale. 2018;11:72-88. doi:10.1039/C8NR05520C

44. Montazerabadi A, Beik J, Irajirad R, et al. Folate-modified and curcumin-loaded dendritic magnetite nanocarriers for the targeted thermo-chemotherapy of cancer cells. Artif Cells Nanomed Biotechnol. 2019;47:330-340. doi:10.1080/21691401.2018.1557670

45. Lu Q, Dai X, Zhang P, et al. $\mathrm{Fe}_{3} \mathrm{O}_{4} @$ Au composite magnetic nanoparticles modified with cetuximab for targeted magneto-photothermal therapy of glioma cells. Int J Nanomedicine. 2018;13:2491-2505. doi:10.2147/IJN.S157935
46. Mantso T, Vasileiadis S, Lampri E, et al. Hyperthermia suppresses post-proliferation and tumor growth in murine malignant melanoma and colon carcinoma. Anticancer Res. 2019;39:2307-2315. doi:10.21873/anticanres.13347

47. Ge Y, Zhong Y, Ji G, et al. Preparation and characterization of $\mathrm{Fe}_{3} \mathrm{O}_{4}$ (a)Au-C225 composite targeted nanoparticles for MRI of human glioma. PLoS One. 2018;13(4):e195703. doi:10.1371/journal.pone.0195703

48. Shakeri-Zadeh A, Shiran M-B, Khoee S, et al. A new magnetic nanocapsule containing 5-fluorouracil: in vivo drug release, anti-tumor, and pro-apoptotic effects on CT26 cells allograft model. J Biomater Appl. 2014;29:548-556. doi:10.1177/0885328214536940

49. Beik J, Khademi S, Attaran N, et al. A nanotechnology-based strategy to increase the efficiency of cancer diagnosis and therapy: folate-conjugated gold nanoparticles. Curr Med Chem. 2017;24:4399-4416. doi:10.2174/ 0929867324666170810154917
International Journal of Nanomedicine

\section{Publish your work in this journal}

The International Journal of Nanomedicine is an international, peerreviewed journal focusing on the application of nanotechnology in diagnostics, therapeutics, and drug delivery systems throughout the biomedical field. This journal is indexed on PubMed Central, MedLine, CAS, SciSearch ${ }^{\circledR}$, Current Contents ${ }^{\mathbb{R}} /$ Clinical Medicine,
Dovepress

Journal Citation Reports/Science Edition, EMBase, Scopus and the Elsevier Bibliographic databases. The manuscript management system is completely online and includes a very quick and fair peer-review system, which is all easy to use. Visit http://www.dovepress.com/ testimonials.php to read real quotes from published authors. 